IZA DP No. 4273

Immigration to the Land of Redistribution

Tito Boeri

June 2009 


\title{
Immigration to the Land of Redistribution
}

\author{
Tito Boeri \\ Bocconi University, \\ Fondazione Rodolfo Debenedetti, \\ CEPR and IZA
}

Discussion Paper No. 4273

June 2009

IZA

P.O. Box 7240

53072 Bonn

Germany

Phone: +49-228-3894-0

Fax: +49-228-3894-180

E-mail: iza@iza.org

Any opinions expressed here are those of the author(s) and not those of IZA. Research published in this series may include views on policy, but the institute itself takes no institutional policy positions.

The Institute for the Study of Labor (IZA) in Bonn is a local and virtual international research center and a place of communication between science, politics and business. IZA is an independent nonprofit organization supported by Deutsche Post Foundation. The center is associated with the University of Bonn and offers a stimulating research environment through its international network, workshops and conferences, data service, project support, research visits and doctoral program. IZA engages in (i) original and internationally competitive research in all fields of labor economics, (ii) development of policy concepts, and (iii) dissemination of research results and concepts to the interested public.

IZA Discussion Papers often represent preliminary work and are circulated to encourage discussion. Citation of such a paper should account for its provisional character. A revised version may be available directly from the author. 


\section{ABSTRACT \\ Immigration to the Land of Redistribution*}

Negative perceptions about migrants in Europe, the Continent with the largest social policy programmes, are driven by concerns that foreigners are a net fiscal burden. Paradoxically instruments of social inclusion are becoming a weapon of mass exclusion. Increasing concerns of public opinion are indeed pressing Governments, in the midst of the recession, to reduce welfare access by migrants or further tighten migration policies. Are there politically feasible alternatives to these two hardly enforceable (and procyclical) policy options? In this paper we look at economic and cultural determinants of negative perceptions about migrants in Europe. Based on a simple model of the perceived fiscal effects of migration and on a largely unexploited database (EU-Silc), we find no evidence that legal migrants, notably skilled migrants, are net recipients of transfers from the state. However, there is evidence of "residual dependency" on non-contributory transfers and self-selection of migrants more likely to draw on welfare in the countries with the most generous welfare state. Moreover, redistribution does not find much support among those who are in favour of immigration. A way out of the migration into the welfare state dilemma facing Europe involves i. coordinating safety nets across the EU, ii. adopting explicitly selective migration policies, and iii. improving activation programmes. Other options - such as restricting migration or welfare access by migrants - are however on the agenda of national Governments.

JEL Classification: J38, J5

Keywords: migration policy, welfare access, fiscal externality

Corresponding author:

Tito Boeri

IGIER

Università Bocconi

Via Roentgen, 1

20136 Milano

Italy

E-mail: tito.boeri@unibocconi.it

\footnotetext{
* The author wishes to thank Michele Pellizzari for valuable comments, Pietro Biroli and Tommaso Colussi for unflagging research assistance and the EC for financial support in the context of the project "Politics, Economics and Global Governance: The European Dimensions" (PEGGED), Seventh Research Framework Programme, Contract number 217559.
} 


\section{Introduction}

Europe is the main land of attraction of immigrants. Over the last 20 years 26 million people migrated to Europe compared with 23 to the US, 1.6 to Australia and 0.5 to Japan. Since the beginning of the new Millennium countries like Ireland and Spain experienced a doubling of their foreign to domestic population ratios. Europe is also the land of redistributive policies as it devotes to social policies a larger fraction of GDP than any other Continent or large country in the world. Paradoxically these policies, explicitly aiming at promoting social inclusion, are inducing many support to social exclusion. Mounting concerns of the EU population with respect to immigration are indeed driven by the fear that migrants represent a fiscal burden, mainly because they drain public resources as recipients of the generous social transfers introduced in Europe to prevent social exclusion. It is precisely for this reason that national Governments are tightening up migration policies and cutting on welfare access by migrants. This does not seem to reduce migration flows, nor to significantly affect the skill content of migration. The only visible outcome is that policy instruments devised to promote social inclusion are quite paradoxically becoming weapons of mass exclusion.

The situation is just getting worse in the current recession, which is hitting particularly hard the European countries that attracted most of the migrants in the last decade. Governments are reacting by tightening migration policies and cutting on welfare access by migrants. Both policies are hardly enforceable, and reduce the assimilation of those migrants who are already in Europe. They also create asymmetries which are hard to swallow on equity grounds. Moreover, cutting on welfare payments to those who are particularly vulnerable to shocks reduces the work of automatic stabilizers just while they should be fully operational to counteract the recession. However, also doing nothing is not an option as the spread of xenophobic movements highlighted by the June 2009 vote for the European Parliament - indicates that migration is a major source of social tensions.

In this paper we discuss ways out of this policy dilemma. We start by characterising the evolution of sentiments of Europeans vis-à-vis migrants, identifying the main determinants of the mounting negative perceptions concerning their role in society. We find that fiscal externalities associated with migration are the main source of concerns about migrants. In other words, the problem is in the interaction between migration and the welfare state. Thus, we develop a simple model enabling us to identify the main interactions, the channels by which migration may affect taxes and benefits received by natives. Guided by this model, we then go back to the data and analyse available evidence on the (static) net fiscal position of migrants, on their "residual dependency" on social transfers and on the role played by social transfers in the self-selection of low-skilled migrants to Europe. We also look at the, admittedly scant, evidence available on perceptions about redistribution and identity of Europeans. Our main findings are that there are both economic and cultural reasons for the growing concerns of Europeans. The policy response so far involved a tightening of migration restrictions and cuts on welfare access by migrants. We argue, in the last section of the paper, that these policies are ineffective in addressing the concerns of public opinion in the long-run and discuss alternative strategies to decouple migration from the welfare state, dealing with the policy dilemma faced by Europe.

The structure of the paper is as follows. Section Two dwells on perceptions of Europeans about migrants. Section Three develops a simple model on migration, welfare access and taxation of 
natives. Section Four, evaluates the net fiscal position of migrants and their residual dependency on welfare. Finally, Section Five discusses policy options for Europe.

\section{Perceptions of Migration and the Welfare State}

We document in this section that perceptions of Europeans with respect to migration are deteriorating and that a driving force of these perceptions are concerns over the net fiscal position of migrants.

\subsection{Overall Perceptions}

Table 1 draws on two waves of the European Social Survey, an EC-sponsored cross-sectional survey initiated in 2002. The focus is on the five largest recent immigration EU countries. The fraction of respondents is displayed who agree with general statements as to the overall social and economic desirability of immigration. In particular, individuals agree that "it is bad for [country]'s economy that people come to live here from other countries" or that "[country] is made a worse place to live by people coming here to live from other countries". There is also a question on the desirability of measures forcing jobless migrants to leave, i.e. "people who come here to live and are unemployed for a long period, should be made to leave". This question unfortunately was not repeated in 2006, but a very similar one was included in a February 2009 Harris survey: "Do you support government asking immigrants to leave the country if they do not have a job”?

As shown by the table, negative perceptions appear to be increasing over time in all countries. Although the ESS and the Harris surveys are not strictly comparable, the support to measures forcing unemployed migrants to leave has grown significantly during the current recession. In all countries a majority of citizens was in February 2009 in favour of repatriating migrants becoming long-term unemployed. Previous work on preferences over immigration policy (Scheve and Slaughter, 2001; Boeri et al., 2002; Mayda and Rodrik, 2001 and O’Rourke, 2003) also found increasing concerns over the economic consequences of migration, notably among the unskilled workers.

Table 1

Perceptions in the largest EU immigration countries

\begin{tabular}{crrrrrr}
\hline \hline $\begin{array}{l}\text { \% of respondents agreeing } \\
\text { with the following statements }\end{array}$ & Germany & Spain & $\begin{array}{r}\text { United } \\
\text { France } \\
\text { Kingdom }\end{array}$ & Italy ${ }^{\mathbf{1}}$ \\
\hline "immigration bad & ESS 2002 & 29 & 23 & 28 & 43 & 25 \\
for country's & ESS 2006 & 38 & 24 & 39 & 45 & 41 \\
economy" & $\mathbf{2 0 0 6 - 2 0 0 2}$ & $\mathbf{9}$ & $\mathbf{1}$ & $\mathbf{1 1}$ & $\mathbf{2}$ & $\mathbf{1 6}$ \\
\hline "immigrants & ESS 2002 & 33 & 34 & 37 & 41 & 39 \\
make country & ESS 2006 & 41 & 35 & 42 & 46 & 54 \\
$\begin{array}{c}\text { worse place to } \\
\text { live" }\end{array}$ & $\mathbf{2 0 0 6 - 2 0 0 2}$ & $\mathbf{7}$ & $\mathbf{1}$ & $\mathbf{5}$ & $\mathbf{5}$ & $\mathbf{1 4}$ \\
\hline $\begin{array}{c}\text { "unemployed } \\
\text { immigrants }\end{array}$ & ESS 2002 & 50 & 25 & 32 & 53 & 49 \\
should be made & Harris 2009 & 67 & 71 & 51 & 78 & 79 \\
to leave" & $\mathbf{2 0 0 9 - 2 0 0 2}$ & $\mathbf{1 7}$ & $\mathbf{4 6}$ & $\mathbf{1 9}$ & $\mathbf{2 5}$ & $\mathbf{3 0}$ \\
\hline \hline
\end{tabular}

Notes: 1) The ESS survey took place in Italy only in 2002 and 2004. 


\subsection{Disentangling the main sources of concern}

What drives negative perceptions of Europeans with respect to migrants? The 2002 wave of the ESS included a battery of questions on specific dimensions of the immigration problem. This enables us, limited to this wave, to identify the main drivers of negative perceptions. In particular, questions were included as to the perceived fiscal position of migrants, the effects of migration on job opportunities and wages of natives, as well as on poverty and crime rates.

Table 2 displays a multivariate analysis of the determinants of the sentiments of Europeans visa-vis migrants, pooling cross-sectional observations across all countries covered by the 2002 ESS wave. All variables are expressed as 0-5 indexes (some were actually in a 0-10 range, but were rescaled for the purpose of comparability): where 0 means full agreement and 5 full disagreement. The dependent variable relates to the overall assessment of the economic role of migrants (“immigration is good or bad for our economy?"). Among the independent variables, indexes capturing concerns about the net fiscal position of migrants ("Most people who come to live here work and pay taxes. They also use health and welfare services. On balance, do you think people who come here take out more than they put in or put in more than they take out?"), the effects on poverty and unemployment rates (averaging scores for two questions ${ }^{1}$, namely "immigrants take jobs away" and "harm prospects of the poor"), wages ("average wages are reduced by migrants") and crime ("immigrants make [country]'s crime rate worse"). These indexes have a significant independent variation, as documented by the pairwise correlation coefficients displayed in Annex A (Table A1).

All regressions allow for country dummies. We also include covariates capturing personal characteristics such as age, gender, educational attainment, citizenship, labour market status, income level, presence of migrants among relatives or friends, and ideology. We run a simple linear OLS regression as the various indexes (with the partial exception of the crime index) are distributed over the entire range of "grades" (see Table A2 in Annex A reporting the cumulative density function of the various indexes).

The single most important individual characteristic affecting perceptions is education: highly educated individuals have a much more favourable perception of migrants than persons with secondary or lower education. This prompt us to report, in columns (3) the regression limited to persons with primary or lower education and, in column (4), those of persons with tertiary education. It is also noticeable that the fact of having immigrants as relatives or friends significantly improves perceptions.

As far as the indexes are concerned, the net fiscal position of migrants is by and large the main driver of negative perceptions, followed by concerns over poverty among natives and crime. In particular, an increase by one unit of the fiscal drain sub-index involves a 32 per cent variation in the overall perception index The second most important determinant of negative perceptions,

\footnotetext{
${ }^{1}$ Dustmann and Preston (2004) carried out a factor analysis of these indexes finding that the question on job opportunities had a much stronger effect on the perceived net fiscal position than on the labour market (wage) index.
} 
namely concerns about migration-related poverty and unemployment, can also be interpreted as a by-product of concerns about migration-related welfare access.

The fiscal sub-index (as well as the other sub-indexes) may capture concerns with respect to the overall scale of migration. In column (2) we include among the regressors the perceived share of immigrants in the population, as reported by each interviewee. The magnitude of the coefficient for the fiscal sub-index (and the other sub-indexes) is unaffected by the inclusion of this additional variable. Nor does the perceived immigration rate significantly affect the coefficient for education. Notice that both high and low educated individuals appear to believe that migrant to population ratios are significantly larger than those reported by official statistics (by a factor of 3,14 in the case of low skilled individuals and by a factor of 2,42 in the case of individuals with tertiary education, see Fig A1 in Annex A). Thus, better perceptions of migrants by highly educated natives do not seem to be due to a different perception of the overall scale of migration. Rather, they point to a differential effects of immigration on individuals with high and low educational attainments.

This skilled biased effect of immigration is confirmed by the regressions including only individuals with primary or lower education and individuals with at least tertiary education, which are displayed in the third and fourth columns of Table 2. They suggest that being unemployed affects negatively perceptions about migrants only among the unskilled. Concerns about unemployment related to migration and the crowding out of assistance to the poor are also felt more among the unskilled, while skilled individuals are relatively more concerned about the effects of migration on wages. Finally, concerns about crime are also more important in affecting overall perceptions within the group of individuals with primary or lower education. 
Table 2

Perceptions of migrants and sources of concern (ESS 2002)

\begin{tabular}{|c|c|c|c|c|}
\hline & \multirow[b]{2}{*}{ All } & \multicolumn{3}{|c|}{$\begin{array}{l}\text { Dependent variable: Migrants are bad/good (0-5) for the } \\
\text { economy }\end{array}$} \\
\hline & & all & primary edu & tertiary edu \\
\hline Age & $0.002^{\star \star *}$ & $0.002^{\star \star \star}$ & 0.002 & $0.003^{\star \star \star}$ \\
\hline Male & $\begin{array}{r}0.106^{\star \star *} \\
(9.889)\end{array}$ & $\begin{array}{r}0.104^{\star * *} \\
(9.190)\end{array}$ & $\begin{array}{l}0.069 * * \\
(2.130)\end{array}$ & $\begin{array}{r}0.131 * * * \\
(6.226)\end{array}$ \\
\hline Primary edu & $\begin{array}{r}-0.131^{* * *} \\
(-6.910)\end{array}$ & $\begin{array}{r}-0.124^{\star * *} \\
(-6.096)\end{array}$ & & \\
\hline Tertiary edu & $\begin{array}{r}0.132^{* * *} \\
(9.752)\end{array}$ & $\begin{array}{r}0.123^{* * *} \\
(8.847)\end{array}$ & & \\
\hline Unemployed & $\begin{array}{r}-0.020 \\
(-0.759)\end{array}$ & $\begin{array}{r}-0.027 \\
(-0.959)\end{array}$ & $\begin{array}{c}-0.134^{*} \\
(-1.652)\end{array}$ & $\begin{array}{r}0.018 \\
(0.277)\end{array}$ \\
\hline Inactive & $\begin{array}{r}0.003 \\
(0.083)\end{array}$ & $\begin{array}{r}-0.007 \\
(-0.186)\end{array}$ & $\begin{array}{r}-0.143 \\
(-1.560)\end{array}$ & $\begin{array}{r}0.074 \\
(0.752)\end{array}$ \\
\hline Retired & $\begin{array}{r}0.006 \\
(0.333)\end{array}$ & $\begin{array}{r}0.009 \\
(0.467)\end{array}$ & $\begin{array}{r}0.020 \\
(0.431)\end{array}$ & $\begin{array}{r}-0.012 \\
(-0.293)\end{array}$ \\
\hline Student & $\begin{array}{l}0.059^{\star *} \\
(2.221)\end{array}$ & $\begin{array}{l}0.057^{\star *} \\
(2.080)\end{array}$ & $\begin{array}{r}0.065 \\
(0.629)\end{array}$ & $\begin{array}{r}-0.024 \\
(-0.473)\end{array}$ \\
\hline Self-employed & $\begin{array}{r}0.006 \\
(0.376)\end{array}$ & $\begin{array}{r}0.000 \\
(0.029)\end{array}$ & $\begin{array}{r}0.010 \\
(0.247)\end{array}$ & $\begin{array}{r}-0.043 \\
(-1.335)\end{array}$ \\
\hline Immigrant & $\begin{array}{r}0.133^{\star \star \star} \\
(6.714)\end{array}$ & $\begin{array}{r}0.146^{\star \star \star} \\
(7.098)\end{array}$ & $\begin{array}{c}0.131^{*} \\
(1.907)\end{array}$ & $\begin{array}{r}0.114^{\star \star * *} \\
(3.347)\end{array}$ \\
\hline Relative/friend immig & $\begin{array}{r}0.087^{\star * \star} \\
(7.348)\end{array}$ & $\begin{array}{r}0.084^{\star \star *} \\
(6.852)\end{array}$ & $\begin{array}{l}0.081^{\star \star} \\
(2.182)\end{array}$ & $\begin{array}{r}0.109 * \star * \\
(4.643)\end{array}$ \\
\hline Living in city & $\begin{array}{r}0.055^{\star \star *} \\
(4.744)\end{array}$ & $\begin{array}{r}0.061^{* * *} \\
(5.078)\end{array}$ & $\begin{array}{l}0.090 \text { ** } \\
(2.431)\end{array}$ & $\begin{array}{l}0.051^{\star \star} \\
(2.410)\end{array}$ \\
\hline High income & $\begin{array}{r}0.088^{\star \star \star} \\
(4.561)\end{array}$ & $\begin{array}{r}0.071^{\star \star \star} \\
(3.561)\end{array}$ & $\begin{array}{r}-0.035 \\
(-0.486)\end{array}$ & $\begin{array}{r}0.070 \\
(1.591)\end{array}$ \\
\hline Middle income & $\begin{array}{r}0.045^{\star \star \star} \\
(2.861)\end{array}$ & $\begin{array}{c}0.030^{\star} \\
(1.832)\end{array}$ & $\begin{array}{r}0.027 \\
(0.702)\end{array}$ & $\begin{array}{r}-0.001 \\
(-0.022)\end{array}$ \\
\hline Left-wing ideology & $\begin{array}{r}0.010^{\star * *} \\
(4.229)\end{array}$ & $\begin{array}{r}0.008^{\star * *} \\
(3.292)\end{array}$ & $\begin{array}{r}0.007 \\
(1.138)\end{array}$ & $\begin{array}{l}0.011^{\star *} \\
(2.336)\end{array}$ \\
\hline Fiscal drain & $\begin{array}{l}0.318^{\star \star *} \\
(47.888)\end{array}$ & $\begin{array}{l}0.316^{\star \star *} \\
(45.521)\end{array}$ & $\begin{array}{l}0.309 * * * \\
(16.859)\end{array}$ & $\begin{array}{l}0.304^{\star \star *} \\
(22.027)\end{array}$ \\
\hline Poverty/unemployment & $\begin{array}{l}0.182^{\star \star *} \\
(30.525)\end{array}$ & $\begin{array}{l}0.187^{\star \star *} \\
(29.879)\end{array}$ & $\begin{array}{l}0.206^{* \star *} \\
(11.605)\end{array}$ & $\begin{array}{l}0.190^{\star * * *} \\
(16.172)\end{array}$ \\
\hline Crime rates & $\begin{array}{l}0.162^{\star * *} \\
(23.700)\end{array}$ & $\begin{array}{l}0.156 * * * \\
(21.803)\end{array}$ & $\begin{array}{l}0.224^{\star * *} \\
(11.665)\end{array}$ & $\begin{array}{r}0.128 * * * \\
(8.993)\end{array}$ \\
\hline Wage effects & $\begin{array}{l}0.083^{* * *} \\
(14.342)\end{array}$ & $\begin{array}{l}0.078^{\star * \star} \\
(12.824)\end{array}$ & $\begin{array}{r}0.099 * * * \\
(6.020)\end{array}$ & $\begin{array}{r}0.064^{\star * *} \\
(5.487)\end{array}$ \\
\hline Perceived Migration & & $\begin{array}{r}-0.002^{* * *} \\
(-4.708)\end{array}$ & & \\
\hline Constant & $\begin{array}{l}1.227^{\star \star \star} \\
(23.693)\end{array}$ & $\begin{array}{l}0.894^{\star \star *} \\
(15.681)\end{array}$ & $\begin{array}{r}-0.564 \\
(-0.971) \\
\end{array}$ & $\begin{array}{r}0.907^{\star \star \star} \\
(8.437) \\
\end{array}$ \\
\hline Country Dummies & Yes & Yes & Yes & Yes \\
\hline Observations & 20492 & 18657 & 2564 & 4915 \\
\hline R squared & 0.39 & 0.39 & 0.42 & 0.32 \\
\hline
\end{tabular}

Notes: t statistics in brackets, ${ }^{*}$ significant at 10 per cent, ${ }^{* *}$ significant at 5 per cent, ${ }^{* *}$ significant at 1 per cent. 


\subsection{Learning from time-series (and cross-country) variation}

Unfortunately the questions related to specific dimensions of concerns over immigration were not repeated over time. Thus, we cannot evaluate their role in the deterioration of perceptions.

Yet, we could learn about the importance of welfare drain effects from cross-country and timeseries variation in the overall concern index. Table 3 reports the results of a regression run over country averages for the 3 ESS panels available (2002, 2004 and 2006) in which the dependent variable is once again the overall concerns, the same set of individual characteristics listed in Table 2 is controlled for and we add covariates having only cross-country and time-series variation, such as social expenditure over GDP and the (objectively measured) share of lowskilled immigrants in the total population. As our interest is here in the last two variables, we allow them to enter both linearly and with a quadratic term or interacted and we report only these coefficients. Our results suggest that social expenditure is negatively correlated with perceptions and this effect is largely driven by the low-skill content of migration.

Table 3

\begin{tabular}{|c|c|c|c|}
\hline \multirow[b]{2}{*}{ Social expenditure } & \multicolumn{3}{|c|}{$\begin{array}{c}\text { overall economy (1:bad-5:good) } \\
\text { mean-only natives }\end{array}$} \\
\hline & $\begin{array}{r}-0.200^{\star \star \star} \\
(-3.597)\end{array}$ & $\begin{array}{r}-0.212^{\star \star \star} \\
(-3.597)\end{array}$ & $\begin{array}{r}0.028 \\
(1.519)\end{array}$ \\
\hline Social expenditure^2 & $\begin{array}{r}0.006^{\star \star \star} \\
(3.632)\end{array}$ & $\begin{array}{r}0.006^{\star * *} \\
(3.647)\end{array}$ & \\
\hline Low edu immigrants/pop & & $\begin{array}{r}-0.002 \\
(-0.360)\end{array}$ & $\begin{array}{r}0.171^{*} \\
(1.853)\end{array}$ \\
\hline $\begin{array}{l}\text { Soc. Exp * low edu } \\
\text { imm/pop }\end{array}$ & & & $\begin{array}{l}-0.010^{*} \\
(-1.870)\end{array}$ \\
\hline $\begin{array}{l}\text { Observations } \\
R \text { squared }\end{array}$ & $\begin{array}{l}53 \\
.73\end{array}$ & $\begin{array}{l}49 \\
.73\end{array}$ & $\begin{array}{l}49 \\
.66\end{array}$ \\
\hline
\end{tabular}

Notes: t statistics in brackets, * significant at 10 per cent, ** significant at 5 per cent, *** significant at 1 per cent. The regression includes the following means for country and ESS wave (only for the natives) of: gender, age, educational attainments, , labour market status, income, left wing ideology.

Source: ESS 2002-2004-2006

Other indications as to the importance of perceived welfare-drain may come by analysing the effects on overall perceptions of the receipt by the respondents of social transfers (unemployment benefit, redundancy benefit or "any other social benefits or grants"). This variable may capture concern about crowding out of welfare payments associated with migration. Results (available from the author upon request) suggest that the receipt of benefits is negatively associated with perceptions over migrants and this effect holds only for persons with secondary or lower levels of education.

The importance of welfare access in perceptions of Europeans concerning migration is confirmed by earlier waves of the Eurobarometer survey, covering the EU-15 countries. The fraction of respondents agreeing with the statement that "Minority groups exploit the system of 
social welfare" has been increasing from 45 to 51 per cent in the EU15 in the 1994-2000 period. ${ }^{2}$.

\section{Understanding perceptions: theory}

A simple static model of migration is useful at this stage to characterise the main channels by which immigration may affect both the generosity and the desirability of redistributive policies. We shall neglect fiscal effects coming from the labour market, e.g., arising from unemployment related to migration or by wage effects, as these effects would be primarily captured by perceptions about the labour market impact of migration, which are relatively second order in the minds of Europeans. Empirical research on the impact of migration on employment and wages in Europe also suggests that these effects are relatively small (Boeri, Hanson and McCormick, 2002).

\subsection{The model with no labour market effects of migration}

There are two type of agents, skilled and unskilled workers, who are both risk-neutral and can be either employed or unemployed (there is no inactivity in this setting). Welfare of skilled and unskilled workers (denoted by superscripts $S$ and $U$ respectively) is given by:

$$
W^{S}=w_{S}(1-t)
$$

and

$$
W^{U}=w_{U}(1-t)(1-u)+u b
$$

where $w_{i}$ denotes wages, $u_{i}$ is the skill-specific unemployment rate, and $t$ is the proportional tax rate paying the unemployment benefits, assumed to be the only redistributive transfer in this economy. Appropriate assumptions about wage setting make sure that unemployment among skilled workers is always zero so that taxes are for skilled workers a pure transfer to unskilled workers.

The participation constraint requires that $w_{U}(1-t)>b$. Normalize both the skilled and unskilled natives by one so that before migration takes place skilled and unskilled workers are equally represented in the domestic population. Both the level and the skill composition of migration are considered exogenous at this stage. Denote the number of migrants relative to the native population by $m$ and by $0<\gamma<1$ the share of unskilled workers among migrants. Assume further that unemployment is randomly allocated among natives and migrants so that the unemployment rates of natives and migrants are the same.

\footnotetext{
2 Probit regressions (available from the author upon request) of the probability of agreeing with this statement against personal economic characteristics -- such as age, education, income and labour market status -- as well as ideological factors - political location or idiosyncrasies with respect to specific minorities, e.g., Muslim people (the dummy religion captures individuals who would accept migrants, provided that they are not of Muslim religion) explain about 8 per cent of the total variance. Concerns are more widespread among older people, persons with lower levels of education, unemployed people and persons with lower incomes. Although ideological features are also important (political affiliation and religion dummies are all highly significant and in line with a priori expectations), this confirms that self-interest is important in affecting perceptions of welfare abuse.
} 
Benefit levels are set to clear the Government budget per any given tax rate:

$$
b=t \frac{w_{s}(1+(1-\gamma) m)+w_{N}(1+\gamma m)(1-u)}{u(1+\gamma m)+\phi m}
$$

where $-1<\phi<1$ denotes migrants (not) receiving transfers independently of their formal entitlement. This "residual dependency" term captures low take up (when $\phi$ is negative) or abuse (a positive $\phi$ ) of transfers by the migrant population. Notice that abuse does not rule out the possibility that migrants pay contributions and receive transfers at the same time.

Under our assumptions:

$$
\frac{d W}{d m}=-\left(w^{s}+w^{u}(1-u)\right) \frac{d t}{d m}+u \frac{d b}{d m}
$$

so that the effects of migration on welfare of natives are determined solely by the responsiveness of taxes and transfers to migration (the fiscal and benefit externalities). The first term on the right-hand-side of (4) concerns current incomes of the employees, while the second term incomes of unemployed natives. As the latter are those having the worse perceptions of migrants, we will begin by them. Let us consider first the worst scenario for unemployed natives, notably one where tax rates are fixed so that only benefits adjust to migration. Now by (2) and (3) we have that

$$
\frac{d b}{d m}=\frac{t\left[w_{s}(1-\gamma)+w_{u} \gamma\right]-(\gamma u+\phi) b}{u(1+\gamma m)+\phi m}
$$

Equation (5) indicates that the effects of migration on welfare of unemployed natives depend on the net fiscal position of migrants, notably on whether their taxed incomes (first term in the numerator) exceed the amount paid to them in terms of social transfers (second term in the numerator).

Notice that two crucial variables affecting the net fiscal position of migrants are the share of unskilled workers among migrants, $\gamma$, and the residual dependency term, $\phi$.

Consider now the fiscal externality potentially affecting skilled and unskilled employees. Again, we will consider the potentially worst case scenario for them, notably one where the adjustment to migration occurs only on the tax side, i.e., $\frac{d t}{d m}=-\frac{d b}{d m}$.

Thus, once more, the crucial variables are the net fiscal position, the residual dependency term and the skill composition of migration. Notice that it is only this latter mechanism which is perceived by skilled natives. The more the adjustment to migration occurs via the benefit externality, the more skilled natives are insulated from the adjustment. Unskilled natives can instead be hit twice, as workers paying higher taxes, and unemployed receiving lower transfers. 


\subsection{Self-selection}

So far we have considered both the level and the skill content of migration as exogenous. Perceptions of EU citizens are, however, likely to take into account also the opposite causal link, one in which it is the generosity of the welfare state to affect the scale and skill composition of migration, via the self-selection of low-skilled migrants into the countries having a more generous welfare state. The implications of self-selection of migrants on opinions about migration (on preferences with respect to migration policies) have been characterised by Razin, Sadka and Swagel (2002) -- drawing on previous work by Metzler and Richard (1981) -- as well as by Hassler et al. (2002). These models suggest that it is mainly the percentage of low-skill types among migrants to negatively affect views about the acceptability of migration.

The decision rule of migrants in our static framework can be simply modeled as a cost-benefit test comparing net earnings (and transfers) in the country of destination to net earnings in the country of origin. Denoting by $w_{0}$ earnings in the country of origin (the opportunity cost of migration) and by $c$ mobility costs, and taking into account of the budget constraint (3), we have that migration is convenient to skilled workers insofar as:

$$
w_{S}(1-t)>w_{O}+c
$$

whilst the decision rule for the unskilled workers is to migrate if:

$$
w_{u}(1-t)+u b(t)>w_{O}+c
$$

Consider a situation where potential migrants (either skilled or unskilled) differ in terms of mobility costs (e.g., because of a varying distance between the destination country and their countries of origin). The above two inequalities can be solved to define for both skilled and unskilled migrants cutoff mobility costs, ( $c_{s}$ and $c_{u}$ respectively), below which migration takes place, i.e.

$$
c_{S}(t)=w_{O}-w_{S}(1-t) \text { and } c_{u}(t)=w_{O}-w_{u}(1-t)-u b(t)
$$

Differentiating the two cutoff costs with respect to the tax rate we have then that

$$
\frac{d c_{S}}{d t}=w_{s}>0 \text { and } \frac{d c_{u}}{d t}=w_{u}-\frac{d b}{d t} u=-w_{s}<0
$$

It follows that the skill content of migration is decreasing in the generosity of the welfare state, that is $\gamma(t)$ with $\gamma^{c}>0$. Assuming that the distribution of mobility costs for skilled and unskilled (potential) migrants is the same, we also have that changes in the tax rate will only affect the skill composition of migration, without affecting its level, $m$. 


\section{3. $\quad$ Altruism and Identity}

Another extension of our simple model is to allow for preferences for redistribution (Alesina and Giuliano, 2009) and altruism with respect to persons belonging to the same community (Akerlof and Kranton, 2005). This extension is encouraged by the relevance in affecting perceptions of variables capturing the relationship with migrants of respondents (see Section 2). In particular, assume that welfare of skilled workers is decreasing in the amount transferred to the migrants who are not perceived as members of their own community. To the extent that some fraction $0<\varphi<1$ of the transfers to the migrants go to persons perceived as belonging to a different community, we have that:

$$
W^{S}=w_{S}(1-t)-\varphi b(\gamma u+\phi m)
$$

Hence, migration will now affect also welfare of skilled natives even when there is no fiscal externality strictly speaking. Indeed

$$
\frac{d W^{S}}{d m}=-\varphi\left[(\gamma u+\phi m) \frac{d b}{d m}+b \phi\right]
$$

Notice that under these conditions, even when tax rates are fixed, there is a conflict of interest between skilled and unskilled natives. The former are indeed better off if migration reduces the level of the transfers (the first-term on the right-hand side of (7)) paid also to unskilled natives.

\section{Understanding perceptions: data}

The previous two sections suggest that concerns of Europeans are likely to be driven by a negative fiscal position of migrants, which can be by itself a byproduct of residual dependency on state transfers or of a predominance among migrants of persons with lower skills. Another interpretation is that, independently of the net fiscal position of migrants, natives dislike redistribution when perceived to be directed to individuals not belonging to the same community. In this Section we exploit all available data sources to evaluate the relevance of these explanations.

Our main data source in assessing the net fiscal position of migrants and welfare dependency is the EU Survey of Income and Living Conditions (SILC), a standardized annual survey carried out in the European Union since 2004. It provides detailed information on the tax and benefit position of the interviewees and of their families. Unlike the previous EU-wide survey, the European Community Household Panel (ECHP), it identifies all the different sources of incomes of the interviewee and her household and involves relatively large sample sizes, allowing for representation of the migrant population. For the time being only the crosssectional dimension of the EU-SILC is available. Hopefully, in the near future, researchers will have access to the five year panel allowed by the sampling design.

Defining the immigrant status in the EU-SILC is not an easy task. There are two possibilities. The first is to define an immigrant as a non-citizen of any given country. The problem with this 
definition is that it may be biased by cross-country differences in naturalization laws. Moreover, the data files provided to researchers by Eurostat do not allow to identify the country of citizenship. We know only if the individual is a native, a citizen of another EU country or a nonEU citizen. The second option is to use information on the country of birth as a proxy for immigrant status. Here, the source of bias is misclassification of 'true nationals' born abroad for whatever reason as immigrants. Such a misclassification may be a serious source of bias for countries which have former colonies such as France, the U.K., Belgium and Portugal.

Weighing pros and cons of the two alternative definitions, we opted for the former classification. In the analysis below, migrants are therefore defined on the basis of their citizenship. Moreover, we concentrate on immigrants coming from non-EU countries, those contributing the most to immigration and relevant for the design of migration policies in the EU.

\subsection{The net fiscal position of migrants}

EU-SILC data allow to estimate the net fiscal position of migrants by deducting from all transfers declared by the interviewees the taxes and social security contributions paid by the workers and their employers. It is clearly a static notion of the net fiscal position as no consideration is made of the lifetime contributions and benefits paid/received by the different households. This a serious limitation especially when assessing the contributions of migrants to public pension systems. Migrants are also typically younger than natives as the net benefits of migration are increasing in the expected length of the working life. Although large flows of immigrants typically improve pension balances in pay-as-you go systems, contributing to paying the pensions of the current retirees, this can only be a short-term relief: migrants themselves, sooner or later, will draw pensions, being a burden on the future generations. In an actuarially fair pension system, inflows of migrants can only alter the temporal profile of pension outlays and net balances. There are, however, two important qualifications. First a long vesting period to qualify for social insurance, may prevent short-term migrants to reap the benefits of their past contributions. Legal migration, in this context, can improve fiscal positions also in the long-run, in that contributions by short-term migrants do not originate any entitlement to social benefits: the host country is free-riding on social security contributions of migrants. In addition to "social free-riding", a second factor improving the sustainability of the pension system in the destination country is the increase in fertility generally associated with migration. However, the effect of migration on fertility is typically transitory. Within a couple of generations, migrants typically adapt to the fertility rates of natives.

As the EU-SILC did not report gross-wages and taxes for Greece, Italy, and Portugal, these countries had to be dropped from our analysis. Moreover, the EU-SILC does not provide information on employers' social security contributions ${ }^{3}$; thus, we imputed these contributions by applying the rules as detailed by the OECD publication “Taxing Wages” (editions 2003/2004 to 2005/2006). The latter provides a routine for each country belonging to the OECD that can be used to calculate the average employers' social security contributions, conditional on grosswages.

Table 3 suggests that migrants to each European country for which data are available, except Spain, contribute less to tax revenues and social security contributions than implied by their

\footnotetext{
${ }^{3}$ The EU-SILC committee decided that this information will be requested to interviewees only from 2007 onwards.
} 
share in the population. This result is hardly surprising as taxes are progressive in EU countries and social security contributions are proportional to earnings while migrant workers are generally concentrated at the low end of the earning distribution.

Table 3.

\section{Contributions of migrants to taxes and social security contributions}

\begin{tabular}{lccc}
\hline \hline & $\begin{array}{c}(1) \\
\text { Share of taxes paid by } \\
\text { migrants }\end{array}$ & $\begin{array}{c}(2) \\
\text { share of migrants in the } \\
\text { population }\end{array}$ & $(3)$ \\
\hline Austria & $2,93 \%$ & $4,27 \%$ & 0,68 \\
Belgium & $1,45 \%$ & $1,75 \%$ & 0,83 \\
Denmark & $0,86 \%$ & $2,03 \%$ & 0,42 \\
Finland & $0,19 \%$ & $0,65 \%$ & 0,30 \\
France & $1,12 \%$ & $2,63 \%$ & 0,42 \\
Germany & $0,65 \%$ & $1,12 \%$ & 0,58 \\
Ireland & $0,97 \%$ & $1,83 \%$ & 0,53 \\
Luxembourg & $1,42 \%$ & $2,29 \%$ & 0,62 \\
Norway & $0,42 \%$ & $1,41 \%$ & 0,30 \\
Spain & $2,74 \%$ & $2,62 \%$ & 1,05 \\
Sweden & $0,38 \%$ & $1,20 \%$ & 0,32 \\
United Kingdom & $2,41 \%$ & $2,91 \%$ & 0,83 \\
\hline \hline
\end{tabular}

Source: (EU-SILC 2004, 2005, 2006, 2007; yearly averages)

*For this country in the EU-SILC no distinction is made between EU and non-EU migrants

The fact that migrants pay proportionally less taxes and contributions than natives clearly does not imply that they are a fiscal burden. They may indeed also receive proportionally less transfers than natives. Thus, we turn our attention to intakes of social transfers.

Figure 1 displays migrant to natives odds ratios in the receipt of contributory and noncontributory transfers. In order to obtain some information about costs related to the provision of education and health services, we also consider education related allowances (scholarships and tuition waivers for low-income people) as well as the presence of serious health limitations, likely to require frequent health treatment. All ratios concern the EU15 as a whole. A number larger than one denotes a condition in which migrants are over-represented in the population of recipients of that particular category of transfers. As can be seen from Figure 1, migrants are systematically overrepresented among the recipients of non-contributory transfers (social assistance and housing benefits), whilst they are less represented than natives among pensioners, recipients of sickness benefits and beneficiaries of unemployment insurance. Similar results were obtained by drawing on ECHP data and are not reported herein for brevity. Migrants are also over-represented in the receipt of educational allowances and likely to be under-represented in the population of recipients of public health services, according to our admittedly rough measure. 
Figure 1

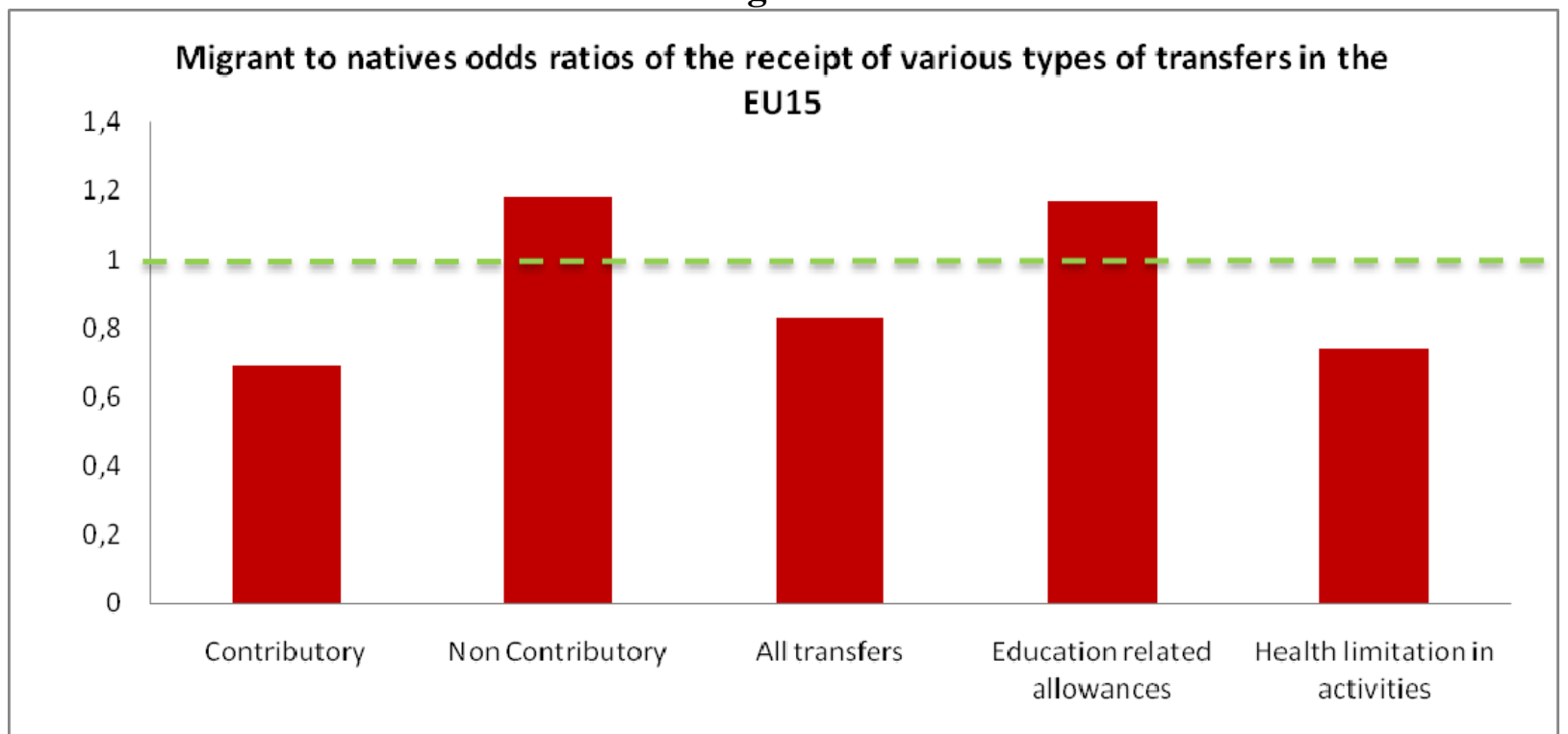

Source: EU-SILC (yearly averages, 2004-2007)

Notes: Health limitation in activities: \% of respondents declaring to have "limitation in activities people usually do because of health problems for at least the last 6 months"

Odds ratios in Figure 1 disentangle contributory from non-contributory schemes as the former do not typically require mobilizing General Government revenues. However, three caveats apply to contributory transfers, which may affect the way in which the generic taxpayer is affected by migration into contributory schemes. First, migrants may have an higher than average exposure to risk of joblessness, which creates gaps in their contribution records and make them net beneficiaries of social security (unemployment benefits and pension minima protecting against labour market risk interacted with longevity risk). Secondly, also the contributory part of social welfare systems often envisages explicit redistributions from the rich to the poor, in addition to those implied by the higher exposure to unemployment risk of the unskilled workers. A number of provisions - such as benefit minima and maxima, a lower degree of indexation of benefits above these floors and eligibility conditions involving some degree of means-testing - introduce even in social insurance programmes an explicit cross-skill redistribution. Replacement rates offered by unemployment benefit systems are, for instance, steeply decreasing with the previous earnings of individuals, notably at rather long unemployment durations (Boeri, Conde-Ruiz and Galasso, 2006). Also public pension systems often involve a fairly large degree of withingeneration redistribution. The so-called "tax component" (non-contributory component) of European pay-as-you-go systems (Disney, 2004) in some countries is even larger than the “contributory (or pure social insurance) component". Put it another way, a large fraction of pension contributions is completely unrelated to future pension rights of contributors. Thirdly, migrants may also have less incentives than natives to seek for jobs when they are receiving social transfers. This means that migrants, feeling less constrained by social values rewarding public spiritedness (Algan and Cahuc, 2006), may have access to contributory schemes over and beyond what implied by their personal characteristics or average risk profile. Under these circumstances, migrants become more "welfare dependent" than natives, draining resources also from contributory schemes. Thus, we provide below estimates of welfare dependency for both contributory and non-contributory transfers. 
Before doing that, it is useful to summarize evidence on the net fiscal position of migrants. Table 4 reports our estimates, obtained by adding up all taxes and contributions that the interviewee declares to have paid and subtracting from those all the transfers received according to the respondent. Among the potential transfers the questionnaire includes contributory transfers such as unemployment, old-age, survivors', sickness and disability benefits as well as non contributory allowances like housing allowances, family-related transfers and subsides that target specific marginalised groups (social exclusion). As no record is made in this context of inkind transfers (such as schooling or free health care), our estimates for the net fiscal position are biased upwards. The overall average net fiscal position is indeed positive in all countries.

With the above caveats in mind, the first column of table 4 displays the share of migrants' who appear to be net contributors to the state budget. The second column shows the odds ratio, that is, the share of net contributors among migrants as a fraction of the share of net contributors among the natives. The third column displays the average net position of migrants and (in brackets) the standard deviation of these estimated individual net fiscal positions. Finally, the fourth column reports the difference in the average net fiscal position of natives and migrants, expressed as a ratio of the average net fiscal position in that country.

Table 4: Net Fiscal Position of migrants

\begin{tabular}{lcccc}
\hline \hline Country & $\begin{array}{c}\text { share of net } \\
\text { contributors } \\
\text { (SNC) among } \\
\text { migrants }\end{array}$ & $\begin{array}{c}\text { SNC: migrants } \\
\text { over natives }\end{array}$ & $\begin{array}{c}\text { Average net } \\
\text { position (ANP) } \\
\text { (euros) }\end{array}$ & $\begin{array}{c}\text { Natives-Migrants } \\
\text { ANP overall }\end{array}$ \\
\hline Austria & $78,3 \%$ & 1,34 & $9481[4210]^{\star \star}$ & 0,40 \\
Belgium & $84,0 \%$ & 0,91 & $11788[3846]^{\star \star *}$ & 0,51 \\
Denmark & $52,2 \%$ & 0,84 & $-1063[8252]$ & $-0,11$ \\
Finland & $47,2 \%$ & 0,80 & $-2863[3285]$ & $-0,32$ \\
France & $44,5 \%$ & 0,81 & $-2285[5207]$ & $-0,27$ \\
Germany & $64,4 \%$ & 1,21 & $3137[5761]$ & 0,42 \\
Ireland & $50,3 \%$ & 1,06 & $-1937[3960]$ & $-0,49$ \\
Luxembourg & $54,9 \%$ & 0,99 & $-1887[9385]$ & 0,88 \\
Norway & $55,7 \%$ & 0,86 & $-1328[5232]$ & 1,14 \\
Spain & $91,7 \%$ & 1,54 & $8047[1674]^{\star \star *}$ & 1,14 \\
Sweden & $49,0 \%$ & 0,77 & $839[4117]$ & 0,96 \\
United & $68,9 \%$ & 1,23 & $12533[4930]^{\star \star}$ & 0,73 \\
Kingdom & & 1,23 & \\
\hline \hline
\end{tabular}

Source: (EU SILC 2004, 2005, 2006, 2007; yearly averages). Standard deviations in parentheses.

*For this country in the EU-SILC no distinction is made between EU and non-EU migrants

The first column of table 4 suggests that generally more than 50 per cent of the migrants are net contributors, according to our estimates. In some countries, notably Austria, Ireland, Spain and the UK migrants are also over-represented in the population of net contributors (second column). This may be due to the fact that we are dealing with countries having recently experienced large inflows of migrants. Recent immigrants are typically much younger than natives and hence do not receive pensions, while they benefit from in-kind transfers, such as schooling for their children. There is also a very large heterogeneity in the net fiscal position of migrants, as documented by the large standard deviations reported in the third column. In those 
countries where the average net fiscal position of migrants is significantly different from zero, the average migrant is a net fiscal contributor and more so than the average native (fourth column). Regressions (reported in Table A1 in the Annex A) estimating the effect of various personal characteristics, including skills, and the migrant status on this net fiscal position suggest that the skill level is a key factor in determining the net fiscal position of natives and migrants: the higher the educational attainment, the better the fiscal position of either natives and migrants.

\subsection{Residual Dependency}

As discussed above, estimated net fiscal positions cannot measure large in-kind transfers to the migrants related to childcare, schooling and medical services. The potential fiscal burden associated with migration can be assessed also by capturing entitlement rules and considering the take-up of state transfers by migrants or their residual dependency, a proxy for the parameter $\phi$ in the model of Section 3. When migrants receive more transfers than those they are entitled to according to the implicit allocation mechanism, they may create pressures also on contributory schemes. Symmetrically, when they have a relatively low take-up of schemes they are formally entitled to, this creates a situation of "social free-riding", in which fiscal revenues in the recipient country are inflated by taxes and contributions which do not actually originate transfers even when the risks that they are supposed to face materialize.

Table 5 reports results of probit regressions evaluating the presence of "residual dependency from social transfers" by non-EU citizens ${ }^{4}$. More precisely, we try to isolate whether the fact of being a migrant explains the take-up of a social transfer in addition to personal characteristics of the individual (e.g., the number of dependent children, educational attainments, family status, etc.) affecting the probability of receiving the transfer. Put it another way, we are asking the following question: would a non-EU citizen be more or less likely to be dependent on a given type of social transfers than a EU citizen with the same characteristics?

\footnotetext{
${ }^{4}$ The full regressions replicating the implicit allocation mechanism of cash transfers are reported in Tables A2 and A3 in the Annex A. They explain up to 70 per cent of the total variance in take-up rates. Once more, the skill level of either natives and migrants is a key factor in affecting the probability of receiving cash transfers.
} 
Table 5.

Residual Dependency on State Transfers of Migrants

\begin{tabular}{|c|c|c|c|}
\hline & & Extra & EU25 \\
\hline \multirow[t]{2}{*}{ Austria } & Contributory & -0.01 & [0.59] \\
\hline & non contributory & -0.07 & {$[3.39]^{* * *}$} \\
\hline \multirow[t]{2}{*}{ Belgium } & Contributory & -0.20 & {$[14.35]^{* * *}$} \\
\hline & non contributory & 0.14 & {$[3.84]^{* * *}$} \\
\hline \multirow[t]{2}{*}{ Denmark } & Contributory & 0.06 & {$[3.52]^{* * *}$} \\
\hline & non contributory & 0.04 & [0.98] \\
\hline \multirow[t]{2}{*}{ Finland } & Contributory & 0.07 & {$[3.03]^{* * *}$} \\
\hline & non contributory & 0.16 & {$[3.00]^{* * *}$} \\
\hline \multirow[t]{2}{*}{ France } & Contributory & -0.10 & {$[7.07]^{* * *}$} \\
\hline & non contributory & 0.29 & {$[11.02]^{* * *}$} \\
\hline \multirow[t]{2}{*}{ Germany $^{+}$} & Contributory & 0.03 & {$[2.02]^{* *}$} \\
\hline & non contributory & 0.15 & {$[3.95]^{* * *}$} \\
\hline \multirow[t]{2}{*}{ Greece } & Contributory & -0.08 & {$[5.12]^{* * *}$} \\
\hline & non contributory & -0.05 & {$[3.49]^{* * *}$} \\
\hline \multirow[t]{2}{*}{ Ireland } & Contributory & -0.19 & {$[8.54]^{* * *}$} \\
\hline & non contributory & -0.03 & [0.71] \\
\hline \multirow[t]{2}{*}{ Italy } & Contributory & 0.00 & {$[0.22]$} \\
\hline & non contributory & -0.01 & [0.95] \\
\hline \multirow[t]{2}{*}{ Luxembourg } & Contributory & -0.10 & {$[5.83]^{* * *}$} \\
\hline & non contributory & 0.10 & {$[2.00]^{* *}$} \\
\hline \multirow[t]{2}{*}{ Netherlands } & Contributory & -0.13 & {$[1.83]^{*}$} \\
\hline & non contributory & 0.42 & {$[2.86]^{* * *}$} \\
\hline \multirow[t]{2}{*}{ Portugal } & Contributory & -0.12 & {$[4.42]^{* * *}$} \\
\hline & non contributory & -0.18 & {$[5.46]^{* * *}$} \\
\hline \multirow[t]{2}{*}{ Spain } & Contributory & -0.09 & {$[6.60]^{* * *}$} \\
\hline & non contributory & -0.02 & {$[2.91]^{* * *}$} \\
\hline \multirow[t]{2}{*}{ Sweden } & Contributory & -0.24 & {$[12.62]^{* * *}$} \\
\hline & non contributory & 0.01 & {$[0.34]$} \\
\hline \multicolumn{4}{|l|}{ United } \\
\hline \multirow[t]{2}{*}{ Kingdom } & Contributory & -0.15 & {$[8.66]^{* * *}$} \\
\hline & non contributory & -0.22 & {$[10.22]^{* * *}$} \\
\hline
\end{tabular}

Source: EU-SILC 2004-7

Note: $\mathrm{z}$ statistics in brackets, * significant at 10 per cent, ** significant at 5 per cent, *** significant at 1 per cent. The regression includes the following covariates: gender, age (linear and quadratic terms), dummies for the number of children, family size, educational attainments, house ownership, labour market status of the respondent and of the partner. See Table A2 and A3 in the Annex A.

Table 5 points to residual dependency of migrants on non-contributory transfers in Belgium, Finland, France, Germany, Luxembourg and The Netherlands and low take-up rates for this kind of transfers in Greece, Portugal, Spain and the UK. Most countries denote a low take-up of contributory transfers of migrants, the exception being in this case Denmark and Germany.

\subsection{Selection effects}

The model in Section 3 also suggests that natives may be concerned about the self-selection of low-skilled migrants driven by "welfare magnets". This risk can be perceived particularly by 
native low skilled workers who are particularly vulnerable to the downscaling of welfare programmes.

As long as the presence of a generous welfare system self-selects migrants who are more exposed to unemployment risk, notably low-skilled migrants, immigration can put pressures also on contributory systems. However, eligibility to contributory transfers typically requires a minimum contribution period, preventing immigrants to draw benefits before a vesting period, which can be relatively long (e.g., in the case of pensions can be up to five years).

Skilled migrants are certainly not randomly allocated across the EU. There are striking disparities among EU countries regarding the educational attainments of migrants vis-à-vis the natives Table 6 displays the evolution of the relative share of skilled workers (persons with tertiary educational attainments) in the non-EU migrant population vis-à-vis the native population, a proxy for the parameter $\gamma$ in the model of section 3. Data are drawn from Docquier (2006) dataset on the stocks of migrants and natives by education and from the Barro-Lee (2000) dataset on educational attainments.

Table 6

Relative of share of skilled workers among migrant and natives

\begin{tabular}{lccc}
\hline \hline \multicolumn{3}{c}{$\begin{array}{c}\text { Ratio of the share of individuals with tertiary education } \\
\text { in the migrant } \\
\text { population and the same share in the } \\
\text { native population }\end{array}$} \\
\hline Country & $\begin{array}{c}\text { Relative } \\
\text { Share '90 }\end{array}$ & $\begin{array}{c}\text { Relative } \\
\text { Share '00 }\end{array}$ & $\begin{array}{c}\boldsymbol{\Delta} \\
\mathbf{2 0 0 0}-\mathbf{1 9 9 0}\end{array}$ \\
\hline Spain & 2,19 & 1,15 & $-1,05$ \\
Portugal & 1,85 & 1,03 & $-0,82$ \\
Greece & 1,79 & 0,99 & $-0,80$ \\
Italy & 1,60 & 0,91 & $-0,69$ \\
Germany & 1,98 & 1,36 & $-0,61$ \\
Norway & 1,48 & 1,05 & $-0,43$ \\
Ireland & 2,83 & 2,50 & $-0,33$ \\
Netherlands & 1,08 & 0,87 & $-0,21$ \\
France & 1,32 & 1,12 & $-0,20$ \\
Belgium & 1,05 & 0,87 & $-0,18$ \\
Austria & 0,77 & 0,71 & $-0,06$ \\
Finland & 1,03 & 1,01 & $-0,02$ \\
Denmark & 0,78 & 0,81 & 0,03 \\
United & & & \\
Kingdom & 1,67 & 1,83 & 0,16 \\
Sweden & 1,11 & 1,29 & 0,18 \\
\hline \hline
\end{tabular}

Sources: Own extrapolations on data from Docquier (2006) and Barro-Lee (2000)

The table points to quite striking differences in the relative skill content of migration across EU countries, suggesting that skills of migrants are not randomly allocated in Europe. A rather common trend is a deterioration over time of the relative skill content of migration to Europe (third column).

How do the observed cross-country differences in the relative skill content of migration correlate with differences in the generosity of welfare system? Table 7 offers a panel regression 
of the relative shares displayed in Table 6 against several measures of the generosity of social policies in the OECD countries ${ }^{5}$. The first two regressions allow for regional dummies (Continental, Eastern, Northern and Southern Europe, North-America, Asia and Oceania) while the last two on the right-hand-side are in differences, hence control for fixed country effects.

Table 7

Relative skill composition of migrants and the generosity of social policies in the OECD

\begin{tabular}{|c|c|c|c|c|}
\hline & \multicolumn{2}{|c|}{$\begin{array}{l}\text { Dependent variable: } \\
\text { Relative skill ratio }\end{array}$} & \multicolumn{2}{|c|}{$\begin{array}{l}\text { Dependent variable: } \\
\text { Difference in Relative } \\
\text { skill ratio (2000-1990) }\end{array}$} \\
\hline & (1) & (2) & (3) & (4) \\
\hline \multirow[t]{2}{*}{ Active labor market programmes } & & $0.386^{*}$ & & 0.141 \\
\hline & & $(1.97)$ & & $(0.547)$ \\
\hline \multirow[t]{2}{*}{ Housing polizie } & & 0.113 & & -0.491 \\
\hline & & $(0.064)$ & & (1.04) \\
\hline \multirow[t]{2}{*}{ Unemployment benefits } & & 0.028 & & $0.301^{* *}$ \\
\hline & & $(0.31)$ & & $(2.37)$ \\
\hline \multirow[t]{2}{*}{ Total social expenditure } & $-0.085^{\star \star \star}$ & $-0.091^{\star \star \star}$ & $-0.065^{\star *}$ & $-0.113^{\star \star \star}$ \\
\hline & $(-5.23)$ & $(-4.64)$ & $(-2.69)$ & $(-3.59)$ \\
\hline \multirow[t]{2}{*}{ Constant } & $2.092^{\star \star \star}$ & $2.442^{\star \star \star}$ & -0.071 & -0.044 \\
\hline & $(6.73)$ & $(5.85)$ & $(-0.92)$ & $(-0.49)$ \\
\hline Regional mummie & yes & yes & No & no \\
\hline Observations & 57 & 45 & 27 & 21 \\
\hline$R$ squared & 0.48 & 0.46 & 0.22 & 0.54 \\
\hline
\end{tabular}

Source: OECD and own elaborations on data from Docquier (2006)

Notes: In columns (3) \& (4) independent variables are given by differences between 2000 and 1990.

Consistently with the simple model outlined in section 3, Table 7 suggests that higher social expenditure is generally associated with a lower skill content of migration. However, not all social transfers affect skills in the same direction. Active labour market policies and unemployment benefits, in particular, appear to positively affect the relative skill content of migration.

The presence of more unskilled immigrants in the countries and time-periods with higher social spending does not necessarily imply that self-selection is at work. As suggested by the political economic models by Benhabib (1996) and Dolmas and Huffman (2003), the causality may also go from the skill composition of migrants to welfare policies rather than the other way round. Cross sectional data can hardly shed light on the direction of causality.

A recent study by De Giorgi and Pellizzari (2008) drawing on ECHP data, found that crosscountry asymmetries in the generosity of social welfare systems, can increase significantly the

\footnotetext{
5 One may argue that differences in the educational attainments of migrants vs. natives across European countries reflect differences in the quality of the workforce in the source countries, which are history dependent. But the above pattern survives even after controlling for the origin of immigrants. For instance, Boeri et al. (2002) compared the two main recipients of African migrants, namely France and the U.K., finding that in France roughly $33 \%$ of Africans had not completed secondary education, vs. only $18 \%$ of Africans in the U.K.
} 
scale of migration flows, having also some impact on the skill composition of migration. In particular, De Giorgi and Pellizzari found that an increase by one standard deviation in the generosity of welfare benefits (involving an increase of their amount by roughly 3,000 $€$ per year in a country) accrues the probability of receiving migrants by some $3 \%$. This is a sizeable effect. All the interactions with personal characteristics are not significant except the skill and the gender interactions, pointing to some positive selection of the unskilled and negative selfselection of women in countries with a generous welfare system (perhaps because migrant women fill the gaps of social security in providing childcare and support to the elderly). Unfortunately, we could not have access to the panel of EU-SILC, hence we cannot carry out the same type of analysis with this data source that provides a much deeper description of social transfers received by individuals.

\subsection{Identity and preferences for redistribution}

As suggested by our findings above, non-contributory transfers involve in several countries significant residual dependency with migrants receiving more than implied by the implicit allocation rule of these transfers. Under these circumstances, preferences over redistribution are likely to play a major role in the perception of migration. Unfortunately there is limited information on preferences over redistribution (see Alesina and Giuliano, 2009 for a review) and even this scant evidence is available only for a few countries.

Table 8 below reports the fraction of natives who agree with the statement that "Governments should take more responsibility to ensure that everybody is provided for" and who perceive migrants as members of the same community. In particular, the share of people in any given country is displayed who not only support redistributive policies but also either do not indicate migrants among the persons they would not like to have as their neighbors (second column) or who declare to be in a favour of permissive migration policies (third column). These intersections offer proxies for the parameter $(1-\varphi)$ of the model in Section 3.

Table 8

Identity and support to redistributive policies

\begin{tabular}{lccc}
\hline \hline & $\begin{array}{c}\text { Support to } \\
\text { redistributive policies }\end{array}$ & $\begin{array}{c}\text { Support to } \\
\text { redistributive } \\
\text { policies and do } \text { not } \\
\text { mind having } \\
\text { immigrants as } \\
\text { neighbours }\end{array}$ & $\begin{array}{c}\text { Support to } \\
\text { redistributive } \\
\text { policies and in } \\
\text { favour of } \\
\text { permissive } \\
\text { migration policies }\end{array}$ \\
\hline All & 41,01 & 33,92 & 19,81 \\
Italy & 44,21 & 35,92 & 25,74 \\
Spain & 50,5 & 44,85 & 23,73 \\
Sweden & 17,61 & 16,19 & 12,89 \\
Finland & 26,98 & 21,36 & 13,54 \\
Germany & 52,88 & 41,63 & 21,28 \\
\hline \hline
\end{tabular}

Source: WVS 2005

The key message delivered by Table 8 is that preferences for redistribution are only partly associated with a perception of migrants as members of the same community: the intersection among the two sets involves a relatively small component of the population in the host country. Thus, it is quite possible that migrants are indeed perceived as non deserving the same 
redistribution which is desirable for the members of the same community. There is no reciprocity in this sentiment: a majority of migrants (between 57\% in Italy and $95 \%$ in Spain) are perceiving themselves as citizens of the host country.

Overall, there is evidence that migrants are overrepresented among recipients of noncontributory systems, and in countries with a rather generous welfare state (the Nordics and Continental EU countries) this overrepresentation is not only explained by their personal characteristics, such as the presence of many dependent family members exposing them more than natives to unemployment and poverty risks. Lower skills are always associated with a higher fiscal burden of migration and the relative small content of migration has been diminished notably in those countries with a more generous social policy system. Identity considerations may also play a role in growing concerns of Europeans about the fiscal costs of migration: a relatively small fraction of EU citizens are favourable to redistribution and, at the same time, consider migrants as members of the same community. Thus, all the various factors discussed in the simple model presented in Section 3 would seem to be at work in Europe.

\section{Decoupling Migration and Welfare: Policy Issues}

\subsection{How Governments are reacting}

European Governments are reacting to growing concerns of their citizens with respect to migration and welfare, by either tightening migration policies or closing welfare doors to migrants or via combinations of both policies, which in an attempt to decouple migration from welfare policy.

Table 9 displays the evolution of a summary indicator of the strictness of migration policies (see Annex B for details as to how the indicator is defined). Limited to some country we also have a variable displaying changes in the stance of migration policies limited to the highly skilled workers. This information is provided in the last column on the right-hand-side of Table 9.

Table 9 suggests that all EU15 countries except Greece have been tightening migration policies. Some liberalisation has taken place limited to highly skilled migrants (persons with tertiary or postgraduate education). The mounting concerns about the economic and social impact of migration documented in Section 2 are now pressing Governments to make migration policies even more restrictive. 
Table 9: Evolution of migration policies in Europe (1994-2005)

\begin{tabular}{|c|c|c|c|}
\hline & & \multicolumn{2}{|c|}{ Strictness Index } \\
\hline & & Total & $\Delta$ High skilled \\
\hline \multirow[t]{2}{*}{ Austria } & 1994 & 2,33 & \\
\hline & 2005 & 2,79 & \\
\hline \multirow[t]{2}{*}{ Denmark } & 1994 & 2,67 & 0 \\
\hline & 2005 & 3,21 & 0 \\
\hline \multirow[t]{2}{*}{ Finland } & 1994 & 2,17 & \\
\hline & 2005 & 2,79 & \\
\hline \multirow[t]{2}{*}{ France } & 1994 & 1,33 & 0 \\
\hline & 2005 & 1,50 & 0 \\
\hline \multirow[t]{2}{*}{ Germany } & 1994 & 2,50 & 0 \\
\hline & 2005 & 2,57 & -1 \\
\hline \multirow[t]{2}{*}{ Greece } & 1994 & 2,83 & \\
\hline & 2005 & 2,71 & \\
\hline \multirow[t]{2}{*}{ Ireland } & 1994 & 2,75 & \\
\hline & 2005 & 2,93 & \\
\hline \multirow[t]{2}{*}{ Italy } & 1994 & 3,00 & \\
\hline & 2005 & 3,14 & \\
\hline \multirow[t]{2}{*}{ Netherlands } & 1994 & 2,75 & 0 \\
\hline & 2005 & 3,00 & -1 \\
\hline \multirow[t]{2}{*}{ Portugal } & 1994 & 3,00 & \\
\hline & 2005 & 3,07 & \\
\hline \multirow[t]{2}{*}{ Spain } & 1994 & 3,08 & \\
\hline & 2005 & 3,21 & \\
\hline \multirow[t]{2}{*}{ United Kingdom } & 1994 & 2,25 & 0 \\
\hline & 2005 & 2,91 & -1 \\
\hline
\end{tabular}

Another decoupling strategy is restricting welfare access by non-EU migrants. There are several indications that this policy is being implemented by conditioning on citizenship many social transfers. A policy temporarily closing the welfare door to migrants has also been explicitly advocated by the German Council of Economic advisers and, in particular, by Hans-Werner Sinn (2004a, 2004b) as a precondition for having more liberal migration policies.

As suggested by the evidence reviewed in this paper, closing the welfare door would reduce the proportion of unskilled workers in migration inflows. A closing the welfare door policy, however, would postpone the assimilation of migrants who are already in the country or who would come in any event. Thus, it may paradoxically increase the negative externalities on the natives of immigration to rigid labour markets, by pushing many migrants into illegal activities.

The issue is that both strategies - the tightening of national restrictions to migration and a closing the welfare door policy -- are hardly enforceable.

In the EU it is very difficult to enforce different migration policies. Migrants can transit in the countries with milder restrictions to finally settle in the country with a generous social welfare, notably moving across countries subscribing the Schengen agreements. Hence the tightening 
policy may end-up substituting legal with illegal migration, which makes the fiscal position of migrants even worse. Illegal migrants are not in a position to pay taxes and social security contributions while are still entitled to free or subsidised health care and education for their children.

A closing the welfare door may not be a credible policy option under the sizeable immigration flows taking place in Europe. The US experience is revealing in this respect. In 1996, the welfare system was partly decentralized to the states and limitations were introduced to access to welfare benefits for legal immigrants. For instance, legal non-asylum immigrants who arrived in the country after August 1996 were barred from receiving food stamps or using Medicaid for 5 years. The proponents of this reform were hoping that a more decentralised system would make the states more cautious in providing expensive welfare benefits to immigrants. The reform failed on both accounts (Boeri et al., 2002). Since 1996, the provision excluding immigrants from some welfare services has been challenged in the courts. By 1997, the Congress started repealing the tougher provisions. Finally, the states felt the political pressure to maintain the benefits at the previous levels under the federal system with this being particularly evident in high-migration states like California; immigrants account for more than 15 per cent of the Californian electorate. A decentralized system that strongly discriminates against immigrants can face political resistance, is easily challengeable in courts and is thus likely to ultimately revert to the previous system.

Thus, restricting migration or cutting welfare access by migrants, besides raising issues of equity, may not be feasible strategies to decouple migration from welfare policies. Ways out of the European policy dilemmas can be possibly found by considering other policy instruments in combination with migration policies. We consider below the following three decoupling options:

1. introducing a `points-based system' (PBS), rewarding skilled migration;

2. harmonising safety nets at the EU level;

3. increasing the contributory component of social welfare.

\subsection{Adopting a PBS?}

A points based system is a method to rank applications for residence and work permits. It has been adopted by Australia, Canada, New Zealand and, in Europe, by Switzerland. The UK is likewise introducing a PBS. In this system, each application is allocated a score based on explicit criteria which typically reward educational attainment, experience, and language abilities. "Bonus points" can also be given for employment in occupations and regions where there is a shortage of workers. A point-based-system adopted by Europe vis-à-vis third country nationals may encourage more skilled migration not only in relative, but also in absolute terms, enhancing the growth potential of migration and reducing negative externalities via unemployment. An additional advantage of a PBS is that it could simplify migration regulations, e.g. removing the need for ad-hoc policies for highly-skilled migrants and integrating asylum policies into a broader framework by, for example, granting "humanitarian" points. Finally, most EU countries are already introducing de facto selective migration policies, as also documented by Table 9: reforms are mostly reducing strictness for highly skilled workers. A 
PBS would make policies more transparent, providing better signals to migrants choosing the country of destination.

But how effective are points systems in selecting migrants? Some crude indications may come by comparing the distribution of 2004 IALS (International Adult Literacy Scores) scores of migrants vs. natives in a country without a points system (Germany) and in a country with a PBS in place, like Canada (Figure 2). The difference is quite striking in terms of both, absolute skill levels (the average IALS for migrants was roughly 300 in Canada compared with 250 in Germany) and relative to natives. In Germany the skill distribution of migrants is visibly tilted to the left, while in Canada it almost perfectly overlaps with the distribution among natives. However, there may be many other potential explanations for the observed differences in the composition by skill of migration to Canada and Germany, e.g., differences in mobility costs, the generosity of welfare states, historical and geographical factors, etc.. Unfortunately there is no good time-series on quality of education allowing to carry out at least difference-indifferences analyses of the effects of the adoption of a PBS on the skill composition of migration.

An additional reason to introduce a PBS is that economic theory suggests that the skill content of migration affects the state budget via its effects on economic growth. Endogenous growth models (Aghion and Howitt, 1998) imply that immigration contributes to economic growth in the recipient country insofar as it increases the share of skilled workers in the population. By increasing its per capita human capital endowments, the immigration country can support stronger growth rates in GDP per capita, rather than simply experiencing a once-for-all increase in GDP. By the same token, migration having a lower skill content than the native labour force reduces the potential growth rate.

Figure 2

Distribution of average IALS scores in Germany (left) and Canada (right)
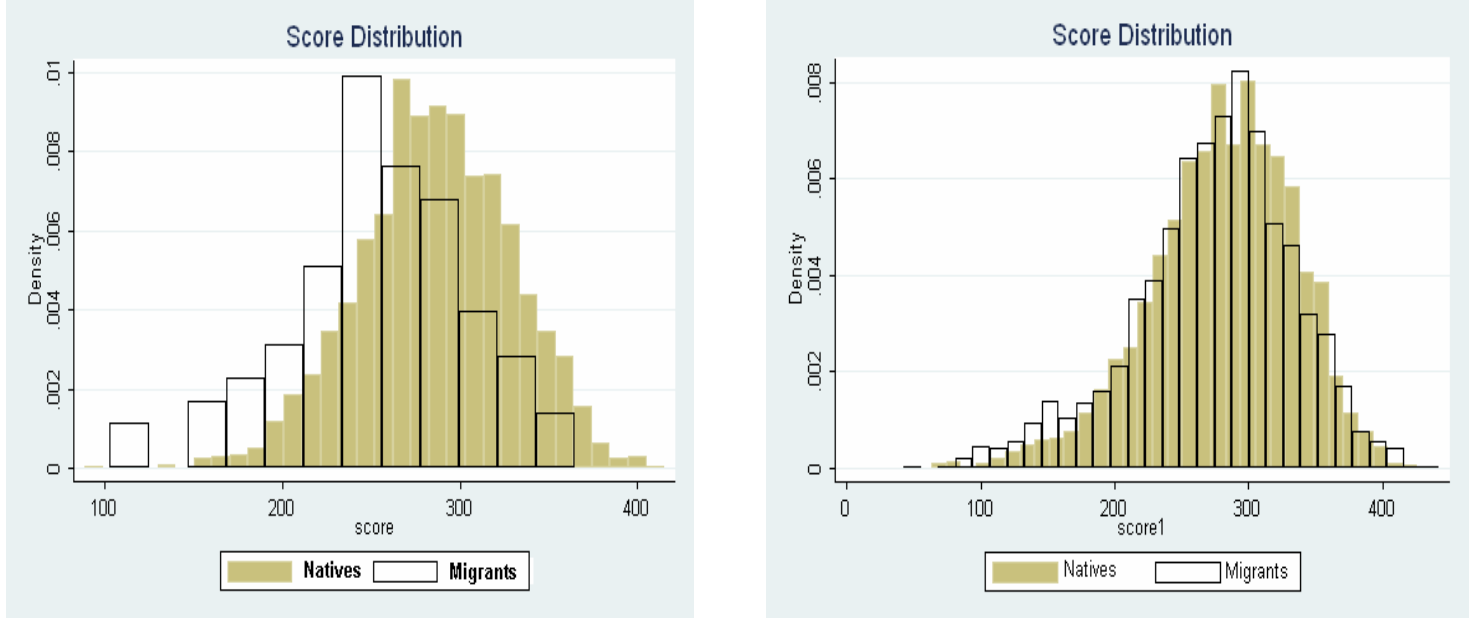

Source: Ials 2004

The key problem facing this strategy is a lack of coordination of migration policies across EU countries. As they share a common border, this policy is bound to be successful only if implemented in a coordinated fashion across the EU. 


\subsection{Harmonising minimum welfare across jurisdictions}

The above policy options have to do with migration policy or the treatment of migrants with respect to their access to social transfers rather than to the design of social policies. Another option involves the harmonization of minimum welfare standards (Bean et al., 1998, Bertola et al., 2001) or a EU-wide minimum welfare floor (see Atkinson, 1998). The rationale for this policy is that it would prevent welfare shopping and potential "races-to-the bottom" in social welfare provision fostered by fiscal spillovers across jurisdictions.

European countries differ quite substantially in terms of the generosity of their welfare systems, and, as shown in Section 4, these differences are correlated with the skill composition of migration.

The potential for a race to the bottom across jurisdictions can be better characterized by a variant of the 1951 Roy model. Suppose that a migrant is considering two alternative destinations, say country 1 or country 2 , and that the only relevant dimension affecting the potential earnings of migrants is skill. The choice faced by the migrant is illustrated in Figure 3, displaying, on the horizontal axis, the skill level of a given individual, and, on the vertical axis, her earnings, net of migration costs.

As shown by the panel on the left-hand-side of Figure 3, the most skilled workers (those with skills higher than $\mathrm{s}^{*}$ ) will go to country 1 , where their skills are better rewarded, while the least skilled will go to country 2 , as they are paid more therein. 
Figure 3. The choice of the destination country and the welfare floor

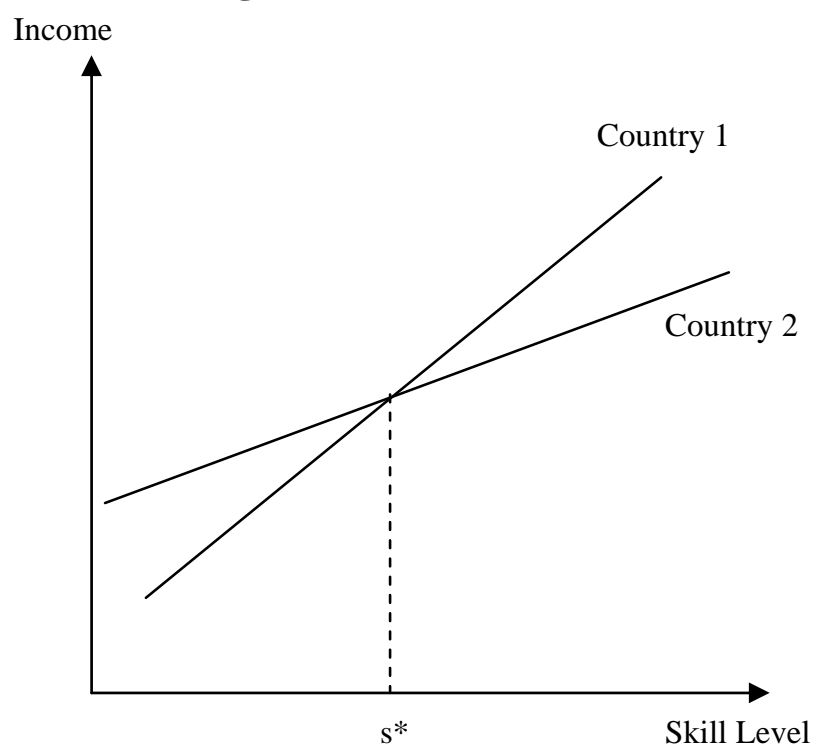

Skilled migrants go to country 1 Unskilled migrants go to country 2

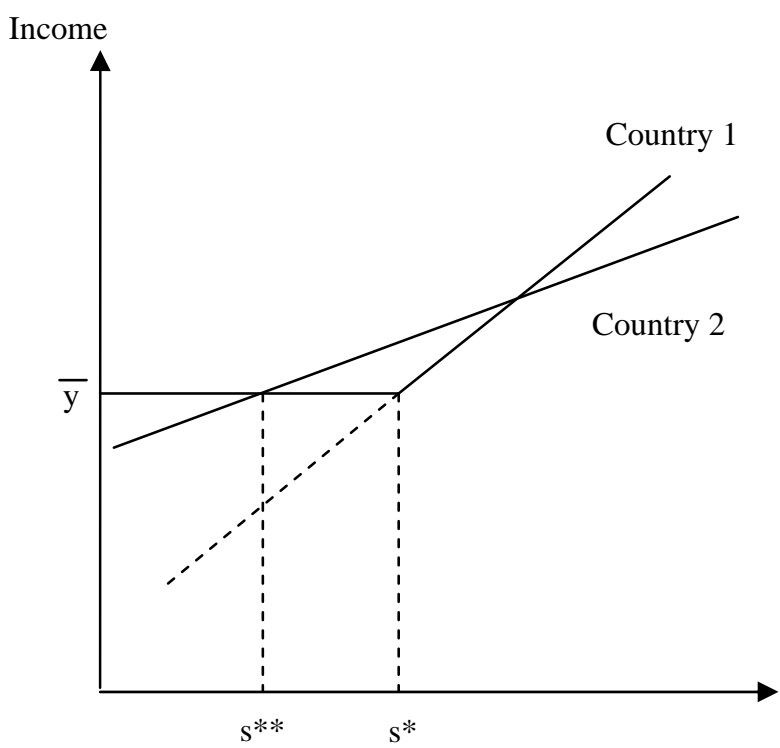

Safety net in country 1 : also the least skilld go to country 1

Suppose now that country 1 introduces a minimum guaranteed income scheme, preventing natives' and migrants' incomes to fall below a given poverty threshold, say $\bar{y}$. Now also some of the unskilled (those with skills lower than $s^{* *}$ ) will migrate to country 1 . Therefore, the presence of a welfare state affects the skill composition of migration, and may induce some workers not to go where their skills are mostly productive, exerting a welfare magnet effect.

Because of this a fiscal externality across jurisdictions, countries with a rich welfare state are bound to attract more migrants than countries with a poor safety net or no safety net at all. Moreover, it will be mainly the unskilled migration to be diverted by asymmetries among potential destinations of migrants in the generosity of the welfare state. Larger inflows of unskilled migrants are also bound to increase earning inequalities in the country attracting more migrants. This may further increase, via second round effects, social expenditure in the recipient. Although, as shown in Section 4, there is limited evidence that "welfare magnets" are operating in Europe, these effects are perceived by public opinion, fearing a race to the bottom in welfare provision in order to prevent self-selection to penalize the most generous countries.

All EU countries, except Greece and Italy, have some safety net in place. Yet, coordinating these floors is not an easy task. The very different income levels of EU countries and regions imply that some inter-jurisdictional redistribution is hardly avoidable. Minimum-welfare transfers and services could be co-financed by a specific budget line item at the EU level. How large could this budget line be? De Giorgi and Pellizzari (2006) estimated that a Minimum Guaranteed Income (MGI) scheme harmonised at 430 net monthly euros at purchasing-powerparity for a single without children (this is roughly the average of the MGIs offered in the EU-15 in 2000) would cost about 30 billion euros, which is about $3 / 4$ of the current expenditure for social assistance and housing at the EU level. This sum is significantly smaller than the 
resources currently allotted to Structural, Cohesion, or Common Agricultural Policy funds (which currently amount to some 60 billion euro). Schmitter (1999) also noted that 50 billion euros would more than suffice to lift all EU-15 citizens out of poverty.

An EU minimum welfare program could have negative effects on employment. Some design features of this harmonised MGI are very important in this respect. In order to prevent welfareshopping, the minimum standard needs to be specified in absolute terms (rather than in relation to local incomes). At the same time, cost-of-living differentials and the character of socialservice provision should be taken into account by the definition of country- and region-specific minimum levels of welfare provision. Uniform minimum absolute welfare levels would indeed have the most negative employment effects in relatively poor countries or regions. Minimum assistance levels may then be specified in purchasing power parity terms, and would be much lower in Poland than in Germany. This is a difficult exercise but, to the extent that prices of nontraded goods are lower in the same locations where labor productivity and wages are low, would go some way towards reducing disincentive effects on local labor supply.

At the national level, this MGI could be possibly integrated with Employment ConditionalIncentives (ECIs), reducing marginal effective tax rates above the MGI. Thus, the integration of the MGI within the national tax-and-benefit system is very important to minimize adverse effects on employment.

The definition and specification of European welfare minima might instead be a suitable task for the European Commission, which could be tasked with monitoring local welfare programs to ensure that no European citizen, regardless of her or his residency, employment history, and nationality is allowed to fall through the cracks of an EU-wide safety net. The level of this EUwide poverty prevention programs along the trade-off between poverty prevention and employment is an essentially political decision. As argued by Atkinson (1998), a clear commitment to an official policy in this respect would have beneficial politico-economic implications within each country. Inasmuch as unhindered mobility of persons is a basic building block of the EU, however, the issue must be discussed at the central level: to ensure that actual or potential problems are addressed clearly and to minimize political distortions, the relevant funds should be clearly isolated in the EU budget. Central co-financing of social assistance programs would also provide means for enforcement of EU-wide guidelines: as in the US TANF program, the availability of central matching funds should be conditional on satisfactory implementation of minimum welfare provisions, and activation schemes, and the enforcement power afforded by this financial lever should be exercised by central supervisory bodies.

It is also essential in this context to reach agreement on the definition of EU citizenship, especially as regards entitlements of non-EU immigrants and refugees. In the spirit of social cohesion, all EU legal residents could be fully integrated in the minimal, centrally co-funded welfare program envisioned here. To address the obvious co-ordination problems arising when EU-wide citizenship entitlements are granted by local constituencies, entry into the EU should be centrally regulated, as is envisaged (albeit after a long transition process) by the provisions added in Amsterdam under Title IV of the EU Consolidated Treaties (European Commission, 1998a). 


\subsection{Increasing the Contributory Component of Social Policies}

Harmonising welfare policies across the EU faces the same coordination issues of the adoption of a PBS in Europe. A more feasible option could be then to reform national social policies in order to make them less vulnerable to inflows of potential beneficiaries.

The evidence reviewed in section 4 suggests that migrants are under-represented among beneficiaries of many contributory transfers and that a greater scope of unemployment insurance and activation policies is not associated with inflows of low-skilled migrants. If anything, more contributory transfers would seem to encourage skilled migration.

A possible reform option would be then to make EU social policy systems more Bismarckian or at least strengthen activation measures, reducing job search disincentives associated with the public provision of social assistance. The literature on activation strategies in European countries (Walsh, Atkinsons and Barry, 2000; Boeri, Layard and Nickell, 2000) supports the role of job search assistance and work tests as a way to reduce the duration of claims. Although it is difficult to disantangle the effect of job search assistance from that of benefit sanctions, policies carried out with an experimental design suggest that job search assistance and counselling may have a positive effect on flows from unemployment to employment over and above benefit sanctions and financial incentives.

Policies enforcing strict entitlement rules to unemployment insurance and assistance are also useful in reducing long-term dependency on social welfare. Insufficient action to prevent the loss of a job, refusal to take-up a "suitable" job or to be involved in training schemes can be sanctioned with a reduction in benefit amounts. These policies often develop on rather undetermined legal rules. Among the most relevant issues to be addressed by this set of policies the definition of a "suitable" job offer. The latter requires establishing the amount of travel time required to get to the workplace. In the UK and the Netherlands, for instance, no more than two hours of daily travel are contemplated. In Belgium and Switzerland, the upper limit is four hours, although it is rarely enforced. Occupational protection (allowing unemployed people to refuse job offers involving a change in occupation) is typically provided only at the beginning of an unemployment spell (OECD 2000).

Benefit sanctions (ranging between 5 and 35 per cent of the benefit amount) proved also rather effective in quasi-experiments the Netherlands (Abbring, Van den Berg and Van Ours. 1999; Engelen et al. 1999) and in Switzerland (Lalive, Van Ours and Zweimüller 2000). Abbring, Van den Berg and Van Ours (1999), in particular, estimate that job finding rates doubled after the imposition of the sanctions: the re-employment rates of males increased by $61 \%$ in the metal industry and $36 \%$ in the banking sector. For females the increase in re-employment rates was even higher. Overall, benefit sanctions proved rather effective in reducing unemployment duration. A more precise legal framework, in addition to reducing the degree of arbitrariness of administrations in using these activation measures, would make it easier to evaluate the effects of these measures. 


\section{Final Remarks}

There is a widespread and growing perception in Europe that migrants are a fiscal burden and abuse its generous welfare states. This view induces negative perceptions about migration to Europe which is almost unavoidably taking place. The poorest and the least educated individuals of the EU are those most concerned about the fiscal implications of migration. Negative perceptions are milder among skilled workers and natives having migrants as relatives or friends. This suggests that economics and psychology are more important than ideology in explaining this growing dissatisfaction of Europeans with respect to migrants.

In this paper we developed a simple model accounting for the various channels by which migration can affect the perceived fiscal impact of migration. Based on this framework we then analysed all the data sources available to evaluate the importance of each of these factors. We found that migrants are overrepresented among beneficiaries of non-contributory transfers, and some evidence of "residual dependency" of migrants, thereby they receive transfers more than natives when control is made of their educational attainments and family characteristics, notably in the countries with the richest welfare state. More social spending would seem also to be associated with a lower skill content of migration which, in turn, negatively affects the net fiscal position of migrants.

Growing negative perceptions about migrants are supporting policies decoupling migration from social policies. The policies so far pursued either restrict migration or welfare access by migrants. Both strategies are, however, hardly enforceable and may turn out to be ineffective beside raising equity issues and making it more difficult the assimilation of migrants.

Alternative decoupling strategies involve adopting selective migration policies, rewarding educational attainments, harmonising social welfare systems or increasing the insurance and pro-work content of social policies. A points-based system, in particular, would counteract an overrepresentation of unskilled workers in the countries with a generous safety net, addressing the self-selection problem documented in this paper. However, adopting a EU-wide PBS would require coordination of policies vis-a-vis legal migration at the European level, a task which is well beyond the current dire state of European policy integration. Harmonising welfare systems also deals with self-selection: it co-ordinates safety nets across countries to prevent potential races to the bottom in minimum standards. But again, policy coordination is an issue. The third option, involves making social policies more proactive. In the words of Richard Layard and Stephen Nickell this strategy applies "the principle of mutual obligation: the state has an obligation to ensure that offers of work are channelled to every unemployed person within a reasonable time after becoming unemployed. But in return the citizen should take advantage of those offers or lose the opportunity of continuing to live on benefit while rejecting them". It may be the only feasible option decoupling migration from welfare at least in the short-run 


\section{References}

Abbring, J., Van den Berg, G. and van Ours, J. (1999), "The Effect of Unemployment Insurance Sanctions on the Transition Rate from Unemployment to Employment", Tinbergen Institute, Rotterdam.

Aghion, P. and Howitt, P. (1998) Endogenous Growth Theory, MIT Press, Cambidge.

Alesina, A. and Giuliano, P. (2009), "Preferences for Redistribution”. NBER Working Paper Series, Vol. w14825, pp. -, 2009.

Algan, Y. and Cahuc, P. (2006) Civic Attitudes and the Design of Labour Market Institutions: Which Countries Can Implement the Danish Flexicurity Model?, CEPR Discussion Papers 5489.

Akerlof, G. and Kranton, R. (2005). "Identity and the Economics of Organizations," Journal of Economic Perspectives, American Economic Association, vol. 19(1), pages 9-32, Winter.

Atkinson, A.B. (1998), Poverty in Europe, Oxford: Blackwell, 1998.

Barro, Robert J. and Jong-Wha Lee,(2000) "International Data on Educational Attainment: Updates and Implications". CID Working Paper No. 42, April 2000

Bean, Charles, S. Bentolila, G. Bertola, J. Dolado (1998) Social Europe: One for All? London: CEPR.

Benhabib, J. (1996) On the Political Economy of Immigration, European Economic Review.

Bertola, G., Jimeno, J.F, Marimon, R. and Pissarides, C. (2001) "EU welfare Systems and Labor Markets: Diverse in the Past, Integrated in the Future?”, in Bertola, G., Boeri, T. and Nicoletti, G. (eds.) Welfare and Employment in a United Europe, MIT Press.

Boeri, T., Layard, R. and Nickell, S. (2000),: "Welfare-to-Work and the Fight Against Longterm Unemployment”, Department for Education and Employment, Research Report, n. 206.

Boeri, T., Conde-Ruiz, J. and Galasso, V. (2006) “The Political Economy of Flexicurity”, mimeo.

Boeri, T. and Bruecker, H. (2005) "Why are Europeans so Tough on Migrants?”, Economic Policy, 44, pp. 629-704.

Boeri, T., G. Hanson and B. McCormick, B. (eds.) (2002) Immigration Policy and the Welfare System, Oxford University Press, Oxford.

Borjas, G.J. (1987) "Self-Selection and the Earnings of Immigrants", American Economic Review, 77, pp. 531-553.

De Giorgi, G. and Pellizzari, M. (2008), "Welfare Migration in Europe and the Costs of an Harmonised Social Assistance”, Mimeo.

Disney, R. (2004) Are contributions to public pensions programmes a tax on employment?, Economic Policy, 39, pp. 267-311.

Docquier, F. and Marfouk, A. (2006). In C. Ozden and M. Schiff (eds). International Migration, Remittances and Development, Palgrave Macmillan: New York .

Docquier, F. and Rappoport, H. (2004), Skilled migration: the perspective of developing countries, mimeo, Stanford.

Dolmas, J. and Huffman, G. (2003), On the Political Economy of Immigration and Income Redistribution, mimeo.

Dustmann, C., M. Casanova, M. Fertig, I. Preston and C.M. Schmidt (2003), The impact of EU enlargement on migration flows, Home Office Online Report 25/03, http://www.homeoffice.gov.uk/rds/pdfs2/rdsolr2503.pdf. 
Engelen, M., Bunt, S. and Samson, L. (1999), Activating instruments in the social assistance law: interim report, SZW, The Hague.

European Commission (1998a) EU Consolidated Treaties. Brussels.

Hassler, J., Krusell, P., Storesletten, K. and F. Zilibotti (2003), The Dynamics of Government: a positive analysis, mimeo.

Hatton, T. (2004) Seeking Asylum in Europe, Economic Policy, vol.19,issue 38.

Lalive, R., Van Ours, J., and Zweimüller, J., (2000), "The Effect of Benefit Sanctions on the Duration of Unemployment," IEW - Working Papers iewwp110, Institute for Empirical Research in Economics.

Mayda, A. and Rodrik, D. (2001), "Why are Some People (and Countries) More Protectionist than Others?", NBER Working Paper No. 8461.

Mayda, A. M. and Patel, K. (2004), “OECD countries migration policies changes. Appendix to International migration: A panel data analysis of the determinants of bilateral flows".

Metzler, A. and S. Richard (1981) A Rational Theory of the Size of Government, Journal of Political Economy.

OECD (2000), Employment Outlook, June 2000 edition.

O'Rourke, K. (2003), Heckscher-Ohlin Theory and Individual Attitudes Towards Globalisation, NBER Working Paper No. 9872.

Razin, A., Sadka, E. and P. Swagel (2002), "Tax Burden and Migration: A political economy theory and evidence", Journal of Public Economics.

Roy, A. (1951) "Some Thoughts on the Distribution of Earnings", Oxford Economic Papers, 3, June, 135-146.

Scheve, K. and Slaughter (2001), "Labor-Market Competition and Individual Preferences Over Immigration Policy", Review of Economics and Statistics.

Schmitter, Philippe C. (1999) "Social Citizenship in a Democratized European Union," European University Institute, working paper.

Sinn, H.-W. (2004a), "Migration and Social Replacement Incomes. How to Protect Low-income Workers in the Industrialized Countries against the Forces of Globalization and Market Integration", Plenary lecture given at the IIPF Congress, Milano, August 2004, forthcoming in International Tax and Public Finance.

Sinn, H.-W. (2004b), "EU Enlargement, Migration and the New Constitution", CESifo Economic Studies, 50(4), pp. 685-707.

Walsh, K., J. Atkinson and J. Barry (2000), The New Deal Gateway: a Labour Market Assessment, Institute for Employment Studies. 
ANNEX A

Table A1: Cross-correlation of perception indexes

\begin{tabular}{l|ccccc}
\hline \hline & $\begin{array}{c}\text { overall } \\
\text { economy }\end{array}$ & Fiscal drain & Poverty/unemployment & Crime rates & Wage effects \\
\cline { 2 - 7 } Overall economy & 1.0000 & & & & \\
Fiscal drain & 0.4927 & 1.0000 & & & \\
Poverty/unemployment & 0.3597 & 0.3756 & 1.0000 & 1.0000 & \\
Crime rates & 0.4409 & 0.3759 & 0.3149 & 0.5054 & 1.0000 \\
Wage effects & 0.3274 & 0.2567 & 0.2372 & \\
\hline \hline
\end{tabular}

Source: ESS 2002

Table A2: Cumulative density function of the perception indexes

\begin{tabular}{l|rrrrr}
\hline \hline \multirow{2}{*}{$\begin{array}{l}\text { Values } \\
1 \text { (agree) }\end{array}$} & $\begin{array}{c}\text { Overall } \\
\text { economy }\end{array}$ & Fiscal drain & Poverty/unemployment & Crime rates & Wage effects \\
\cline { 2 - 6 } 2 & $9,8 \%$ & $13,1 \%$ & $12,8 \%$ & $23,8 \%$ & $10,7 \%$ \\
3 & $25,8 \%$ & $37,7 \%$ & $47,1 \%$ & $58,8 \%$ & $39,5 \%$ \\
4 & $72,9 \%$ & $85,6 \%$ & $65,4 \%$ & $94,9 \%$ & $63,1 \%$ \\
5 (disagree) & $94,1 \%$ & $97,0 \%$ & $88,9 \%$ & $99,0 \%$ & $93,3 \%$ \\
\hline \hline
\end{tabular}

Source: ESS 2002 
Figure A1

Perceived vs. actual migration rate for High and Low skilled

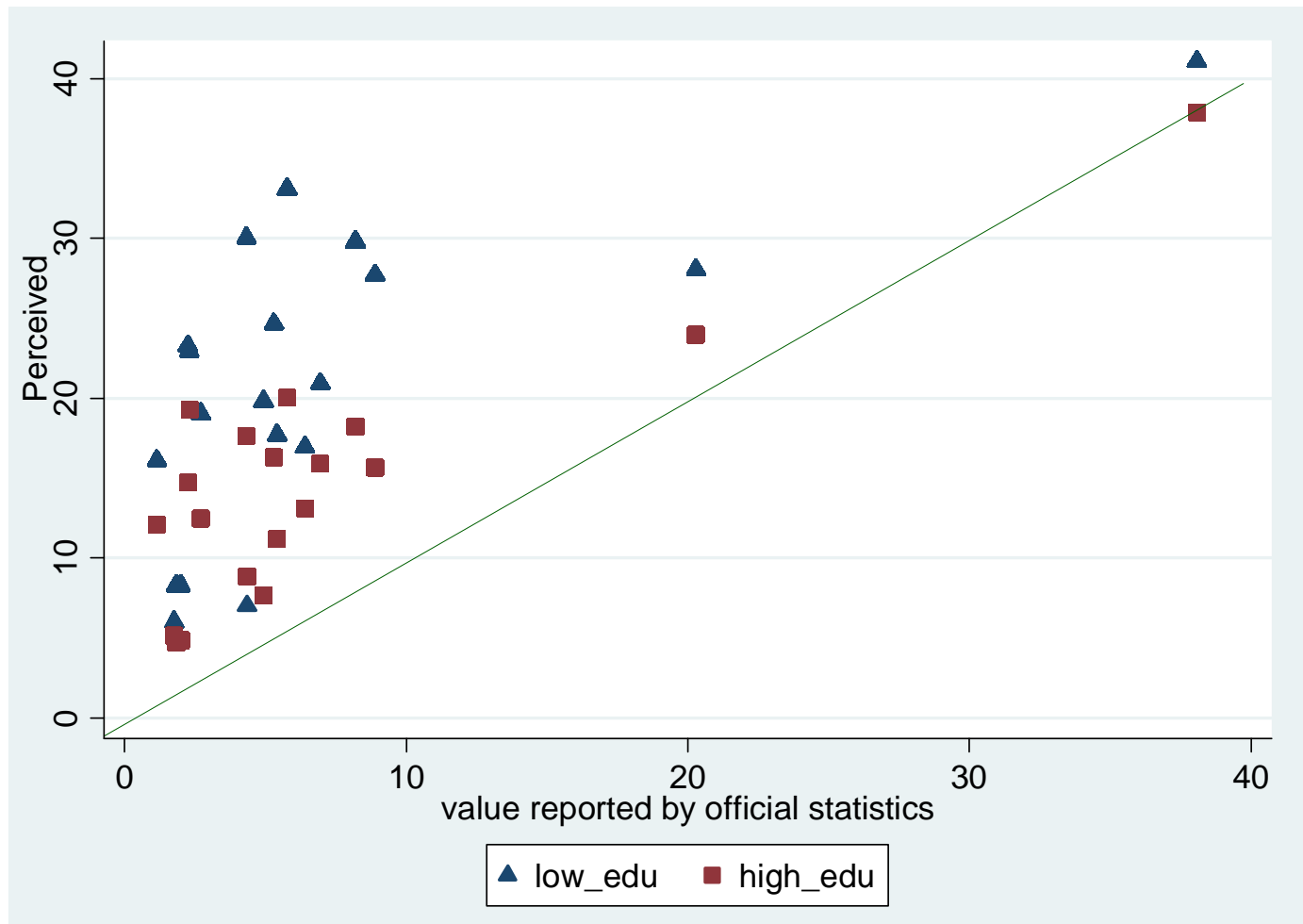

Source: The perceived number of immigrants is obtained from the ESS-2002. The values reported by official statistics come from Eurostat. 
Table A1. Net fiscal position of Households: incidence of individual characteristics

\begin{tabular}{|c|c|c|c|c|c|c|c|c|c|c|c|c|}
\hline & [1] & {$[2]$} & [3] & [4] & {$[5]$} & [6] & [7] & [8] & [9] & [10] & [11] & [12] \\
\hline & AT & $\mathrm{BE}$ & $\mathrm{DE}$ & DK & ES & FI & FR & $\mathrm{IE}$ & LU & NO & SE & UK \\
\hline $\begin{array}{l}\text { EU25 Migrant } \\
\text { House }\end{array}$ & $\begin{array}{l}239.700 \\
{[1,077.920]}\end{array}$ & $\begin{array}{l}3,877.840 \\
{[1,227.667]}\end{array}$ & $\begin{array}{l}0.000 \\
{[0.000]}\end{array}$ & $\begin{array}{l}45.732 \\
{[791.215]}\end{array}$ & $\begin{array}{l}-494.907 \\
{[1,251.587]}\end{array}$ & $\begin{array}{l}11,597.632 \\
{[8,429.553]}\end{array}$ & $\begin{array}{l}354.051 \\
{[602.596]}\end{array}$ & $\begin{array}{l}881.868 \\
{[889.135]}\end{array}$ & $\begin{array}{l}3,136.941 \\
{[648.222]^{* *}}\end{array}$ & $\begin{array}{l}3,353.036 \\
{[1,485.282]}\end{array}$ & $\begin{array}{l}-767.221 \\
{[840.991]}\end{array}$ & $\begin{array}{l}1,241.6 \\
{[1,223 .}\end{array}$ \\
\hline Extra EU25 & $1,802.322$ & $44,325.201$ & 574.725 & $-3,908.112$ & $2,002.173$ & $-5,176.555$ & -107.798 & $-2,986.776$ & $3,163.197$ & -675.785 & $-1,640,050$ & $2,392.1$ \\
\hline Migrant House & {$[429.855]^{* *}$} & {$[23,292.978$} & {$[649.434]$} & {$[614.134]^{* *}$} & {$[406.183]^{* *}$} & {$[710.384]^{* *}$} & {$[478.541]$} & {$[1,363.314]$} & {$[1,404.228]$} & {$[946.482]$} & {$[1,153.191]$} & {$[1,067$.} \\
\hline Mixed Household & $\mid \begin{array}{l}3,137.196 \\
{[695.882]^{* *}}\end{array}$ & $\begin{array}{l}-208.445 \\
{[669.926]}\end{array}$ & $\begin{array}{l}402.112 \\
{[808.277]}\end{array}$ & $\begin{array}{l}449.457 \\
{[669.414]}\end{array}$ & $\begin{array}{l}1,109.720 \\
{[710.924]}\end{array}$ & $\begin{array}{l}-928.323 \\
{[523.515]^{*}}\end{array}$ & $\begin{array}{l}2,917.517 \\
{[988.402]^{* *}}\end{array}$ & $\begin{array}{l}-1,055.394 \\
{[877.992]}\end{array}$ & $\begin{array}{l}2,793.785 \\
{[1,039.191]}\end{array}$ & $\begin{array}{l}2,305.374 \\
{[730.899]^{* *}}\end{array}$ & $\begin{array}{l}-729.018 \\
{[715.253]}\end{array}$ & $\begin{array}{l}2,943.9 \\
{[926.23}\end{array}$ \\
\hline Male & $\begin{array}{l}-387.451 \\
{[274.591]}\end{array}$ & $\begin{array}{l}2,601.535 \\
{[736.640]^{* *}}\end{array}$ & $\begin{array}{l}-258.236 \\
{[212.817]}\end{array}$ & $\begin{array}{l}997.378 \\
{[236.890]^{* *}}\end{array}$ & $\begin{array}{l}-163.140 \\
{[183.937]}\end{array}$ & $\begin{array}{l}475.973 \\
{[185.448]^{\star *}}\end{array}$ & $\begin{array}{l}-259.189 \\
{[223.298]}\end{array}$ & $\begin{array}{l}41.827 \\
{[370.354]}\end{array}$ & $\begin{array}{l}2,134.923 \\
{[766.326]^{* *}}\end{array}$ & $\begin{array}{l}770.097 \\
{[289.696]^{* *}}\end{array}$ & $\begin{array}{l}336.514 \\
{[214.623]}\end{array}$ & $\begin{array}{l}372.720 \\
{[315.34}\end{array}$ \\
\hline Age & $\begin{array}{l}402.337 \\
{[36.244]^{* * *}}\end{array}$ & $\begin{array}{l}1,608.847 \\
{[227.510]^{\star *}}\end{array}$ & $\begin{array}{l}620.198 \\
{[32.746]^{\star * *}}\end{array}$ & $\begin{array}{l}-75.671 \\
{[33.555]^{\star *}}\end{array}$ & $\begin{array}{l}397.825 \\
{[30.089]^{\star * *}}\end{array}$ & $\begin{array}{l}432.638 \\
{[27.574]^{\star * *}}\end{array}$ & $\begin{array}{l}564.938 \\
{[32.718]^{\star * *}}\end{array}$ & $\begin{array}{l}519.483 \\
{[45.769]^{\star * *}}\end{array}$ & $\begin{array}{l}1,289.164 \\
{[96.888]^{\star * *}}\end{array}$ & $\begin{array}{l}339.522 \\
{[39.782]^{* * *}}\end{array}$ & $\begin{array}{l}224.713 \\
{[32.964]^{* *}}\end{array}$ & $\begin{array}{l}627.234 \\
{[48.353}\end{array}$ \\
\hline $\mathrm{Age}^{\wedge} 2$ & $\begin{array}{l}-5.811 \\
{[0.350]^{\star * *}}\end{array}$ & $\begin{array}{l}-17.069 \\
{[2.402]^{\star \star *}}\end{array}$ & $\begin{array}{l}-9.090 \\
{[0.327]^{* * *}}\end{array}$ & $\begin{array}{l}-0.797 \\
{[0.328]^{*}}\end{array}$ & $\begin{array}{l}-5.046 \\
{[0.284]^{* * *}}\end{array}$ & $\begin{array}{l}-5.874 \\
{[0.273]^{\star * *}}\end{array}$ & $\begin{array}{l}-7.223 \\
{[0.318]^{* * *}}\end{array}$ & $\begin{array}{l}-5.982 \\
{[0.403]^{\star * *}}\end{array}$ & $\begin{array}{l}-15.773 \\
{[0.967]^{* * *}}\end{array}$ & $\begin{array}{l}-5.108 \\
{[0.399]^{* * *}}\end{array}$ & $\begin{array}{l}-3.045 \\
{[0.334]^{\star * *}}\end{array}$ & $\begin{array}{l}-8.143 \\
{[0.471]}\end{array}$ \\
\hline $\begin{array}{l}\text { Secondary } \\
\text { Education }\end{array}$ & $\begin{array}{l}-1,431.378 \\
{[221.574]^{* *}}\end{array}$ & $\begin{array}{l}911.953 \\
{[1,022.186]}\end{array}$ & $\begin{array}{l}-1,796.378 \\
{[226.601]^{*}}\end{array}$ & $\begin{array}{l}322.889 \\
{[194.529]^{*}}\end{array}$ & $\begin{array}{l}-445.469 \\
{[203.059]^{* *}}\end{array}$ & $\begin{array}{l}283.889 \\
{[170.532]^{*}}\end{array}$ & $\begin{array}{l}-1,792.162 \\
{[211.225]^{\star *}}\end{array}$ & $\begin{array}{l}-130.960 \\
{[329.487]}\end{array}$ & $\begin{array}{l}-2,577.745 \\
{[541.768]^{*}}\end{array}$ & $\begin{array}{l}755.374 \\
{[266.954]^{\star *}}\end{array}$ & $\begin{array}{l}803.791 \\
{[220.725]^{* *}}\end{array}$ & {$[284.64$} \\
\hline $\begin{array}{l}\text { Tertiary } \\
\text { Education }\end{array}$ & $\begin{array}{l}330.245 \\
{[346.308]}\end{array}$ & $\begin{array}{l}7,889,642 \\
{[1,534,498]}\end{array}$ & $\begin{array}{l}-698.079 \\
{[250.754]^{* *}}\end{array}$ & $\begin{array}{l}3,928.007 \\
{[256.553]^{* *}}\end{array}$ & $\begin{array}{l}1,743.028 \\
{[237.728]^{* *}}\end{array}$ & $\begin{array}{l}4,907.171 \\
{[217.391]^{* *}}\end{array}$ & $\begin{array}{l}3,137.727 \\
{[327.965]^{* *}}\end{array}$ & $\begin{array}{l}8,464.357 \\
{[536,126]^{* *}}\end{array}$ & $\begin{array}{l}4,592.362 \\
{[862.975]^{*}}\end{array}$ & $\begin{array}{l}5,744.985 \\
{[366,414]^{\star *}}\end{array}$ & $\begin{array}{l}6,672.614 \\
{[332.493]^{\star *}}\end{array}$ & $\begin{array}{l}2,691.6 \\
{[538.25}\end{array}$ \\
\hline $\begin{array}{l}\text { High income } \\
\text { (before }\end{array}$ & $\begin{array}{l}21,187.086 \\
{[267.368]^{* *}}\end{array}$ & $\begin{array}{l}25,071.651 \\
{[1,131.160]}\end{array}$ & $\begin{array}{l}18,683.168 \\
{[210.271]^{* *}}\end{array}$ & $\begin{array}{l}22,509.574 \\
{[432.903]^{\star *}}\end{array}$ & $\begin{array}{l}12,370,431 \\
{[189.774]^{* *}}\end{array}$ & $\begin{array}{l}23,250.368 \\
{[298.663]^{\star *}}\end{array}$ & $\begin{array}{l}23,502.142 \\
{[253.946]^{\star *}}\end{array}$ & $\begin{array}{l}20,996.654 \\
{[372.063]^{* *}}\end{array}$ & $\begin{array}{l}28,385.704 \\
{[674.744]^{* *}}\end{array}$ & $\begin{array}{l}26,281.175 \\
{[343.267]^{\star *}}\end{array}$ & $\begin{array}{l}26,170.759 \\
{[304,252]^{* *}}\end{array}$ & $\begin{array}{l}25,288 . \\
{[364.96}\end{array}$ \\
\hline Low income $(b, t)$ & $\begin{array}{l}-16,688,587 \\
{[246,849]^{*}}\end{array}$ & $\begin{array}{l}-18,061.664 \\
{[919.116]^{*}}\end{array}$ & $\begin{array}{l}-16,853,083 \\
{[236,504]^{*}}\end{array}$ & $\begin{array}{l}-20,617,473 \\
{[204.583]^{*}}\end{array}$ & $\begin{array}{l}-8,286.343 \\
{[218.847]^{*}}\end{array}$ & $\begin{array}{l}-17,305.775 \\
{[148,063]^{*}}\end{array}$ & $\begin{array}{l}-17,481.279 \\
{[239.853]^{*}}\end{array}$ & $\begin{array}{l}-10,503.503 \\
{[337.530]^{*}}\end{array}$ & $\begin{array}{l}-19,138.300 \\
{[639.535]^{* *}}\end{array}$ & $\begin{array}{l}-23,104.229 \\
{[244.598]^{*}}\end{array}$ & $\begin{array}{l}-20,400,805 \\
{[200,816]^{*}}\end{array}$ & {$[269.89$} \\
\hline House Owner & $\begin{array}{l}934.628 \\
{[243.943]^{* *}}\end{array}$ & $\begin{array}{l}501.414 \\
{[500,491]}\end{array}$ & $\begin{array}{l}1,509.217 \\
{[168,332]^{* *}}\end{array}$ & $\begin{array}{l}2,777.002 \\
{[236.754]^{* *}}\end{array}$ & $\begin{array}{l}-2.085 \\
{[246.188]}\end{array}$ & $\begin{array}{l}1,764.273 \\
{[234.644]^{\star *}}\end{array}$ & $\begin{array}{l}1,582.208 \\
{[193.063]^{* *}}\end{array}$ & $\begin{array}{l}2,057.933 \\
{[360,880]^{* *}}\end{array}$ & $\begin{array}{l}-670.139 \\
{[520.189]}\end{array}$ & $\begin{array}{l}898.240 \\
{[293.903]^{* *}}\end{array}$ & $\begin{array}{l}2,395.734 \\
{[209.995]^{* *}}\end{array}$ & $\begin{array}{l}3,299.6 \\
{[233.08}\end{array}$ \\
\hline Single & $\begin{array}{l}-626.569 \\
{[705.407]}\end{array}$ & $\begin{array}{l}-4,718.297 \\
{[2,898.884]}\end{array}$ & $\begin{array}{l}2,764.854 \\
{[520.708]^{* *}}\end{array}$ & $\begin{array}{l}1,491.545 \\
{[729.150]^{* *}}\end{array}$ & $\begin{array}{l}2,361.219 \\
{[478.939]^{* *}}\end{array}$ & $\begin{array}{l}-860.742 \\
{[865.243]}\end{array}$ & $\begin{array}{l}604.086 \\
{[529.190]}\end{array}$ & $\begin{array}{l}1,533.263 \\
{[873.774]^{*}}\end{array}$ & $\begin{array}{l}3,559.201 \\
{[1,557,294]}\end{array}$ & $\begin{array}{l}1,488.451 \\
{[731.813]^{*}}\end{array}$ & $\begin{array}{l}-6,006.061 \\
{[566,872]^{*}}\end{array}$ & {$[1,116$. } \\
\hline Single with $c$ & $\begin{array}{l}-3,031,066 \\
{[726,506]^{* *}}\end{array}$ & $\begin{array}{l}-1,761.070 \\
{[1,894.809]}\end{array}$ & $\begin{array}{l}-2,449.322 \\
{[453.612]^{\star *}}\end{array}$ & $\begin{array}{l}-1,729.187 \\
{[718.361]^{\star *}}\end{array}$ & $\begin{array}{l}-905.227 \\
{[443.363]^{\star *}}\end{array}$ & $\begin{array}{l}-4,548.270 \\
{[655.865]^{\star *}}\end{array}$ & $\begin{array}{l}-658.668 \\
{[490.376]}\end{array}$ & $\begin{array}{l}-2,706.199 \\
{[882.622]^{\star *}}\end{array}$ & $\begin{array}{l}1,079.495 \\
{[2,114.261]}\end{array}$ & $\begin{array}{l}-2,874.207 \\
{[731.237]^{*}}\end{array}$ & $\begin{array}{l}-4,202.717 \\
{[536.849]^{\star *}}\end{array}$ & {$[1,085$.} \\
\hline 1 child & $\begin{array}{l}2,754,455 \\
{[609.082]^{* *}}\end{array}$ & $\begin{array}{l}-834.676 \\
{[792.141]}\end{array}$ & $\begin{array}{l}909.464 \\
{[472.086]^{*}}\end{array}$ & $\begin{array}{l}4,835.320 \\
{[716.738]^{* *}}\end{array}$ & $\begin{array}{l}3,677.121 \\
{[308.263]^{* *}}\end{array}$ & $\begin{array}{l}7,313.241 \\
{[733.234]^{\star *}}\end{array}$ & $\begin{array}{l}4,021.246 \\
{[576.050]^{\star *}}\end{array}$ & $\begin{array}{l}3,592.422 \\
{[1,013.544]}\end{array}$ & $\begin{array}{l}1,605.090 \\
{[1,182,443]}\end{array}$ & $\begin{array}{l}5,280,418 \\
{[656,726]^{\star *}}\end{array}$ & $\begin{array}{l}4,387.422 \\
{[431.121]^{\star *}}\end{array}$ & $\begin{array}{l}3,432.5 \\
{[950.94}\end{array}$ \\
\hline 2 children & $\begin{array}{l}2,085.645 \\
{[757.500]^{* *}}\end{array}$ & $\begin{array}{l}-1,550.504 \\
{[1,385.353]}\end{array}$ & $\begin{array}{l}216.167 \\
{[548.900]}\end{array}$ & $\begin{array}{l}4,916.318 \\
{[792.216]^{* *}}\end{array}$ & $\begin{array}{l}2,474.510 \\
{[630.666]^{* *}}\end{array}$ & $\begin{array}{l}6,394.989 \\
{[651.764]^{* *}}\end{array}$ & $\begin{array}{l}2,638.486 \\
{[793.478]^{* *}}\end{array}$ & $\begin{array}{l}3,131.168 \\
{[860.220]^{*}}\end{array}$ & $\begin{array}{l}4,269.171 \\
{[1,701.280]}\end{array}$ & $\begin{array}{l}5,756.324 \\
{[922.564]^{\star *}}\end{array}$ & $\begin{array}{l}3,893.157 \\
{[817.187]^{* *}}\end{array}$ & $\begin{array}{l}5,134,9 \\
{[2,026 .}\end{array}$ \\
\hline 3 children & $\begin{array}{l}3,347.691 \\
{[3,588.489]}\end{array}$ & $\begin{array}{l}469.938 \\
{[5,226.836]}\end{array}$ & $\begin{array}{l}-6,575.669 \\
{[4,000.837]}\end{array}$ & $\begin{array}{l}-18,981.268 \\
{[10,884.116}\end{array}$ & $\begin{array}{l}7,996.753 \\
{[1,492.200]}\end{array}$ & $\begin{array}{l}-1,397.735 \\
{[6,634.176]}\end{array}$ & $\begin{array}{l}-544.065 \\
{[3,243.644]}\end{array}$ & $\begin{array}{l}-316.058 \\
{[2,802,477]}\end{array}$ & $\begin{array}{l}3,615,448 \\
{[7,226,405]}\end{array}$ & $\begin{array}{l}660.323 \\
{[4,470.941]}\end{array}$ & $\begin{array}{l}-134.199 \\
{[2,684.335]}\end{array}$ & $\begin{array}{l}810.704 \\
{[11,129}\end{array}$ \\
\hline 5 children & $\begin{array}{l}-10,877,897 \\
{[1,070,048]}\end{array}$ & $\begin{array}{l}-19,112.203 \\
{[9,011.136]}\end{array}$ & $\begin{array}{l}12,291.099 \\
{[3,205.101]}\end{array}$ & $\begin{array}{l}14,779.106 \\
{[1,817.934]}\end{array}$ & $\begin{array}{l}0.000 \\
{[0.000]}\end{array}$ & $\begin{array}{l}6,214.094 \\
{[3,150.831]}\end{array}$ & $\begin{array}{l}-11,413.360 \\
{[1,754.949]}\end{array}$ & $\begin{array}{l}3,066.297 \\
{[4,520.084]}\end{array}$ & $\begin{array}{l}0.000 \\
{[0.000]}\end{array}$ & $\begin{array}{l}3,751.141 \\
{[2,161.899]}\end{array}$ & $\begin{array}{l}-24,435.952 \\
{[5,458.065]}\end{array}$ & $\begin{array}{l}0.000 \\
{[0.000]}\end{array}$ \\
\hline $\begin{array}{l}2 \text { household } \\
\text { members }\end{array}$ & $\begin{array}{l}-1,290.720 \\
{[715.555]^{*}}\end{array}$ & $\begin{array}{l}4,926.129 \\
{[3,434.494]}\end{array}$ & $\begin{array}{l}1,370.567 \\
{[513.978]^{\text {* }}}\end{array}$ & $\begin{array}{l}2,953.382 \\
{[728.624]^{* *}}\end{array}$ & $\begin{array}{l}2,070,077 \\
{[456,940]^{* *}}\end{array}$ & $\begin{array}{l}-1,363.420 \\
{[832.924]}\end{array}$ & $\begin{array}{l}-1,578.828 \\
{[532.703]^{\text {* }}}\end{array}$ & $\begin{array}{l}-2,626,280 \\
{[856,059]^{*}}\end{array}$ & $\begin{array}{l}587.041 \\
{[1,484.319]}\end{array}$ & $\begin{array}{l}2,060,807 \\
{[727,020]^{* *}}\end{array}$ & $\begin{array}{l}-3,536.681 \\
{[555.600]^{*}}\end{array}$ & {$[1,072$. } \\
\hline 3 hh members & $\begin{array}{l}-702.325 \\
{[869.230]}\end{array}$ & $\begin{array}{l}7,675.999 \\
{[3,572.477]}\end{array}$ & $\begin{array}{l}2,788,983 \\
{[696.616]^{* *}}\end{array}$ & $\begin{array}{l}8,723,152 \\
{[1,068.111]}\end{array}$ & $\begin{array}{l}1,295.841 \\
{[494.341]^{\star *}}\end{array}$ & $\begin{array}{l}226.830 \\
{[901.865]}\end{array}$ & $\begin{array}{l}544.879 \\
{[703.593]}\end{array}$ & $\begin{array}{l}-3,762.586 \\
{[1,111.435]}\end{array}$ & $\begin{array}{l}-339.565 \\
{[1,926.057]}\end{array}$ & $\begin{array}{l}7,251.233 \\
{[1,061.545]}\end{array}$ & $\begin{array}{l}288.611 \\
{[814.216]}\end{array}$ & {$[1,640$.} \\
\hline $4 \mathrm{hh} \mathrm{m}$ & $\begin{array}{l}2,115.177 \\
{[1,268.468]}\end{array}$ & $\begin{array}{l}11,902.697 \\
{[3,142.472]}\end{array}$ & $\begin{array}{l}5,603.836 \\
{[998.370]^{* *}}\end{array}$ & $\begin{array}{l}7,586.595 \\
{[1,411.850]}\end{array}$ & $\begin{array}{l}2,910,685 \\
{[550,453]^{* *}}\end{array}$ & $\begin{array}{l}3,231.791 \\
{[1,698.017]}\end{array}$ & $\begin{array}{l}2,805.490 \\
{[954,943]^{* *}}\end{array}$ & $\begin{array}{l}-2,504.087 \\
{[1,556,656]}\end{array}$ & $\begin{array}{l}4,041.543 \\
{[2,504.749]}\end{array}$ & $\begin{array}{l}8,585.376 \\
{[1,386.268]}\end{array}$ & $\begin{array}{l}2,114.463 \\
{[1,024.993]}\end{array}$ & {$[2,128$. } \\
\hline 5 hh members & $\begin{array}{l}3,475.366 \\
{[1,380.355]}\end{array}$ & $\begin{array}{l}14,128.225 \\
{[4,139.548]}\end{array}$ & $\begin{array}{l}9,765.085 \\
{[2,438.097]}\end{array}$ & $\begin{array}{l}19,278.075 \\
{[6,050.731]}\end{array}$ & $\begin{array}{l}2,357.383 \\
{[746.491]^{\star *}}\end{array}$ & $\begin{array}{l}3,633.534 \\
{[1,451.893]}\end{array}$ & $\begin{array}{l}822.025 \\
{[1,386.257]}\end{array}$ & $\begin{array}{l}-1,110.809 \\
{[1,938.547]}\end{array}$ & $\begin{array}{l}6,847.932 \\
{[3,421.316]}\end{array}$ & $\begin{array}{l}10,001.359 \\
{[2,252.987]}\end{array}$ & $\begin{array}{l}4,811.975 \\
{[1,713.914]}\end{array}$ & {$[2,324$. } \\
\hline 6 hh members & $\begin{array}{l}5,442.001 \\
{[1,484.384]}\end{array}$ & $\begin{array}{l}12,621.995 \\
{[3,274.973]}\end{array}$ & $\begin{array}{l}10,930.590 \\
{[1,155.542]}\end{array}$ & $\begin{array}{l}13,094.317 \\
{[1,683.129]}\end{array}$ & $\begin{array}{l}2,057.430 \\
{[1,388.681]}\end{array}$ & $\begin{array}{l}8,215.886 \\
{[1,849.987]}\end{array}$ & $\begin{array}{l}9,029.322 \\
{[1,297.789]}\end{array}$ & $\begin{array}{l}-1,508.502 \\
{[1,870.969]}\end{array}$ & $\begin{array}{l}4,519.568 \\
{[2,971.791]}\end{array}$ & $\begin{array}{l}17,539.070 \\
{[1,724.648]}\end{array}$ & $\begin{array}{l}12,245.678 \\
{[1,494.151]}\end{array}$ & $\begin{array}{l}738.613 \\
{[2,327 .}\end{array}$ \\
\hline 7 hh members & $\begin{array}{l}12,792.854 \\
{[1,764.543]}\end{array}$ & $\begin{array}{l}25,267.129 \\
{[3,553.517]}\end{array}$ & $\begin{array}{l}17,437,665 \\
{[1,389.923]}\end{array}$ & $\begin{array}{l}18,428.217 \\
{[2,426.794]}\end{array}$ & $\begin{array}{l}737.253 \\
{[2,746.021]}\end{array}$ & $\begin{array}{l}15,390.997 \\
{[1,976.556]}\end{array}$ & $\begin{array}{l}12,223.647 \\
{[1,596.413]}\end{array}$ & $\begin{array}{l}-523.690 \\
{[2,051.242]}\end{array}$ & $\begin{array}{l}11,075.688 \\
{[3,329.141]}\end{array}$ & $\begin{array}{l}24,283.986 \\
{[2,003.514]}\end{array}$ & $\begin{array}{l}21,193.760 \\
{[2,029.144]}\end{array}$ & $\begin{array}{l}5,459,4 \\
{[4,544 .}\end{array}$ \\
\hline $\begin{array}{c}\text { Densly populated } \\
\text { area }\end{array}$ & $\begin{array}{l}-18.568 \\
{[276.486]}\end{array}$ & $\begin{array}{l}46.683 \\
{[487.941]}\end{array}$ & $\begin{array}{l}796.400 \\
{[174.752]^{* *}}\end{array}$ & $\begin{array}{l}1,352.098 \\
{[252.480]^{\star *}}\end{array}$ & $\begin{array}{l}64.775 \\
{[190.394]}\end{array}$ & $\begin{array}{l}1,431.502 \\
{[275.147]^{* *}}\end{array}$ & $\begin{array}{l}-301.200 \\
{[218.690]}\end{array}$ & $\begin{array}{l}438.346 \\
{[482.146]}\end{array}$ & $\begin{array}{l}48.308 \\
{[577.169]}\end{array}$ & $\begin{array}{l}2,028,441 \\
{[285,172]^{\star *}}\end{array}$ & $\begin{array}{l}670.772 \\
{[447.744]}\end{array}$ & [378.79 \\
\hline $\begin{array}{c}\text { Thinly populated } \\
\text { area }\end{array}$ & $\begin{array}{l}-790.549 \\
{[239.999]^{\star *}}\end{array}$ & $\begin{array}{l}-1,204.980 \\
{[750.239]}\end{array}$ & $\begin{array}{l}-378.165 \\
{[219.726]^{*}}\end{array}$ & $\begin{array}{l}-1,061.295 \\
{[202.887]^{\star *}}\end{array}$ & $\begin{array}{l}-151.587 \\
{[191.309]}\end{array}$ & $\begin{array}{l}-651.136 \\
{[175.956]^{\star *}}\end{array}$ & $\begin{array}{l}-427.530 \\
{[244.597]^{\star}}\end{array}$ & $\begin{array}{l}-1,309.493 \\
{[366.216]^{\star *}}\end{array}$ & $\begin{array}{l}-1,094,663 \\
{[646.178]^{*}}\end{array}$ & $\begin{array}{l}126.710 \\
{[281.691]}\end{array}$ & $\begin{array}{l}-2,271.669 \\
{[314.864]^{\star *}}\end{array}$ & $\begin{array}{l}2,447.5 \\
{[1,715 .}\end{array}$ \\
\hline Constant & $\begin{array}{l}3,141,297 \\
{[1,169,444]}\end{array}$ & $\begin{array}{l}-34,525.967 \\
{[7,153.282]}\end{array}$ & $\begin{array}{l}-1,842.560 \\
{[955.144]^{*}}\end{array}$ & $\begin{array}{l}14,284,022 \\
{[1,002,072]}\end{array}$ & $\begin{array}{l}-7,107.397 \\
{[1,145.885]}\end{array}$ & $\begin{array}{l}1,168.767 \\
{[1,163.068]}\end{array}$ & $\begin{array}{l}-7,252.461 \\
{[1,058.555]}\end{array}$ & $\begin{array}{l}-13,753.720 \\
{[1,627.400]}\end{array}$ & $\begin{array}{l}-25,225.140 \\
{[2,744.229]}\end{array}$ & $\begin{array}{l}2,852.267 \\
{[1,138.754]}\end{array}$ & $\begin{array}{l}11,971.339 \\
{[892.767]^{*}}\end{array}$ & {$[2,673$. } \\
\hline Year dummies & Yes & Yes & Yes & Yes & Yes & Yes & Yes & Yes & Yes & Yes & Yes & Yes \\
\hline Regional dummies & Yes & Yes & Yes & Yes & Yes & Yes & Yes & Yes & Yes & Yes & Yes & Yes \\
\hline Observations & 24275 & 14601 & 44326 & 26879 & 24454 & 47888 & 43181 & 24423 & 16545 & 26130 & 27494 & 29108 \\
\hline Pseudo R-squared & 0.65 & 0.17 & 0.63 & 0.62 & 0.62 & 0.59 & 0.59 & 0.46 & 0.61 & 0.61 & 0.64 & 0.42 \\
\hline
\end{tabular}


Table A2. The probability of receiving contributory-benefits: individual probit regressions

\begin{tabular}{|c|c|c|c|c|c|c|c|c|}
\hline & [1] & [2] & [3] & [4] & [5] & [6] & [7] & [8] \\
\hline & AT & $\mathrm{BE}$ & $\mathrm{DE}$ & DK & ES & $\mathrm{FI}$ & FR & GR \\
\hline EU25 Migrant & $\begin{array}{l}-0.088378 \\
{[4.19]^{\star \star \star}}\end{array}$ & $\begin{array}{l}-0.062008 \\
{[5.48]^{\star \star \star}}\end{array}$ & & $\begin{array}{l}-0.020741 \\
{[0.67]}\end{array}$ & $\begin{array}{l}-0.044669 \\
{[2.80]^{\star \star \star}}\end{array}$ & $\begin{array}{l}-0.066021 \\
{[1.99]^{\star \star}}\end{array}$ & $\begin{array}{l}-0.069442 \\
{[4.52]^{\star \star \star}}\end{array}$ & $\begin{array}{l}-0.065671 \\
{[2.22]^{\star \star}}\end{array}$ \\
\hline $\begin{array}{c}\text { Extra EU25 } \\
\text { Migrant }\end{array}$ & $\begin{array}{l}-0.008597 \\
{[0.59]}\end{array}$ & $\begin{array}{l}-0.204711 \\
{[14.35]^{\star \star \star}}\end{array}$ & $\begin{array}{l}0.033166 \\
{[2.02]^{\star \star}}\end{array}$ & $\begin{array}{l}0.064353 \\
{[3.52]^{\star \star \star}}\end{array}$ & $\begin{array}{l}-0.093905 \\
{[6.60]^{\star \star \star}}\end{array}$ & $\begin{array}{l}0.072534 \\
{[3.03]^{\star \star \star}}\end{array}$ & $\begin{array}{l}-0.095840 \\
{[7.07]^{\star \star \star}}\end{array}$ & $\begin{array}{l}-0.075929 \\
{[5.12]^{\star \star \star}}\end{array}$ \\
\hline Male & $\begin{array}{l}0.201286 \\
{[31.02]^{\star \star \star}}\end{array}$ & $\begin{array}{l}0.193247 \\
{[32.16]^{\star \star \star}}\end{array}$ & $\begin{array}{l}0.109161 \\
{[21.79]^{\star \star \star}}\end{array}$ & $\begin{array}{l}-0.007492 \\
{[1.22]}\end{array}$ & $\begin{array}{l}0.172474 \\
{[46.52]^{\star \star \star}}\end{array}$ & $\begin{array}{l}-0.008919 \\
{[1.80]^{\star}}\end{array}$ & $\begin{array}{l}0.109970 \\
{[22.54]^{\star \star \star}}\end{array}$ & $\begin{array}{l}0.158144 \\
{[27.32]^{\star \star \star}}\end{array}$ \\
\hline Age & $\begin{array}{l}-0.002781 \\
{[2.39]^{\star \star}}\end{array}$ & $\begin{array}{l}0.020376 \\
{[22.39]^{\star \star \star}}\end{array}$ & $\begin{array}{l}-0.025345 \\
{[24.75]^{\star \star \star}}\end{array}$ & $\begin{array}{l}0.009623 \\
{[8.02]^{\star \star \star}}\end{array}$ & $\begin{array}{l}-0.001418 \\
{[2.65]^{\star \star \star}}\end{array}$ & $\begin{array}{l}-0.000509 \\
{[0.52]}\end{array}$ & $\begin{array}{l}-0.001923 \\
{[1.99]^{\star \star}}\end{array}$ & $\begin{array}{l}-0.003441 \\
{[3.84]^{\star \star \star}}\end{array}$ \\
\hline $\operatorname{Age}^{\wedge} 2$ & $\begin{array}{l}0.000212 \\
{[16.74]^{\star \star *}}\end{array}$ & $\begin{array}{l}-0.000085 \\
{[9.07]^{\star \star \star}}\end{array}$ & $\begin{array}{l}0.000505 \\
{[45.17]^{\star \star \star}}\end{array}$ & $\begin{array}{l}0.000063 \\
{[4.98]^{\star \star \star}}\end{array}$ & $\begin{array}{l}0.000133 \\
{[24.76]^{\star \star \star}}\end{array}$ & $\begin{array}{l}0.000222 \\
{[20.48]^{\star \star \star}}\end{array}$ & $\begin{array}{l}0.000212 \\
{[19.65]^{\star \star \star}}\end{array}$ & $\begin{array}{l}0.000207 \\
{[22.93]^{\star \star \star}}\end{array}$ \\
\hline $\begin{array}{l}\text { Secondary } \\
\text { Education }\end{array}$ & $\begin{array}{l}0.023683 \\
{[3.32]^{\star \star \star}}\end{array}$ & $\begin{array}{l}0.002220 \\
{[0.35]}\end{array}$ & $\begin{array}{l}0.021783 \\
{[2.97]^{\star \star \star}}\end{array}$ & $\begin{array}{l}-0.019160 \\
{[2.51]^{\star \star}}\end{array}$ & $\begin{array}{l}-0.020968 \\
{[4.50]^{\star \star \star}}\end{array}$ & $\begin{array}{l}0.016931 \\
{[2.69]^{\star \star \star}}\end{array}$ & $\begin{array}{l}0.038242 \\
{[7.05]^{\star \star \star}}\end{array}$ & $\begin{array}{l}0.013319 \\
{[2.09]^{\star \star}}\end{array}$ \\
\hline $\begin{array}{c}\text { Tertiary } \\
\text { Education }\end{array}$ & $\begin{array}{l}-0.009396 \\
{[0.94]}\end{array}$ & $\begin{array}{l}0.008577 \\
{[1.17]}\end{array}$ & $\begin{array}{l}-0.041843 \\
{[4.95]^{\star \star \star}}\end{array}$ & $\begin{array}{l}-0.023186 \\
{[2.63]^{\star \star \star}}\end{array}$ & $\begin{array}{l}-0.007207 \\
{[1.48]}\end{array}$ & $\begin{array}{l}-0.051554 \\
{[7.20]^{\star \star \star}}\end{array}$ & $\begin{array}{l}0.049944 \\
{[6.93]^{\star \star \star}}\end{array}$ & $\begin{array}{l}0.056033 \\
{[6.56]^{\star \star \star}}\end{array}$ \\
\hline $\begin{array}{l}\text { High income } \\
\text { (before }\end{array}$ & $\begin{array}{l}-0.274875 \\
{[31.39]^{\star \star \star}}\end{array}$ & $\begin{array}{l}-0.348130 \\
{[38.58]^{\star \star \star}}\end{array}$ & $\begin{array}{l}-0.234893 \\
{[20.63]^{\star \star \star}}\end{array}$ & $\begin{array}{l}-0.416997 \\
{[46.63]^{\star \star \star}}\end{array}$ & $\begin{array}{l}-0.240680 \\
{[43.23]^{\star \star \star}}\end{array}$ & $\begin{array}{l}-0.401923 \\
{[50.41]^{\star \star \star}}\end{array}$ & $\begin{array}{l}-0.355582 \\
{[53.92]^{\star \star \star}}\end{array}$ & $\begin{array}{l}-0.261638 \\
{[35.39]^{\star \star \star}}\end{array}$ \\
\hline $\begin{array}{l}\text { Low income } \\
\text { (b.t) }\end{array}$ & $\begin{array}{l}0.232760 \\
{[29.11]^{\star \star \star *}}\end{array}$ & $\begin{array}{l}0.274897 \\
{[34.13]^{\star \star \star}}\end{array}$ & $\begin{array}{l}0.227488 \\
{[24.20]^{\star \star \star}}\end{array}$ & $\begin{array}{l}0.150448 \\
{[15.58]^{\star \star \star}}\end{array}$ & $\begin{array}{l}0.059882 \\
{[12.20]^{\star \star \star}}\end{array}$ & $\begin{array}{l}0.136517 \\
{[16.65]^{\star \star \star}}\end{array}$ & $\begin{array}{l}0.098329 \\
{[15.56]^{\star \star \star}}\end{array}$ & $\begin{array}{l}-0.015492 \\
{[2.17]^{\star \star}}\end{array}$ \\
\hline House Owner & $\begin{array}{l}-0.064678 \\
{[8.60]^{\star \star \star}}\end{array}$ & $\begin{array}{l}-0.100297 \\
{[14.43]^{\star \star \star}}\end{array}$ & $\begin{array}{l}-0.110038 \\
{[20.66]^{\star \star \star}}\end{array}$ & $\begin{array}{l}-0.039221 \\
{[5.03]^{\star \star \star}}\end{array}$ & $\begin{array}{l}-0.011103 \\
{[1.70]^{\star}}\end{array}$ & $\begin{array}{l}-0.062156 \\
{[9.35]^{\star \star \star}}\end{array}$ & $\begin{array}{l}-0.036600 \\
{[6.46]^{\star \star \star}}\end{array}$ & $\begin{array}{l}0.015880 \\
{[2.07]^{\star \star}}\end{array}$ \\
\hline Single & $\begin{array}{l}0.136550 \\
{[7.49]^{\star \star \star}}\end{array}$ & $\begin{array}{l}0.023189 \\
{[1.53]}\end{array}$ & $\begin{array}{l}0.036445 \\
{[2.49]^{\star \star}}\end{array}$ & $\begin{array}{l}-0.202294 \\
{[9.37]^{\star \star \star}}\end{array}$ & $\begin{array}{l}0.080262 \\
{[8.34]^{\star \star \star}}\end{array}$ & $\begin{array}{l}0.070382 \\
{[4.47]^{\star \star \star}}\end{array}$ & $\begin{array}{l}-0.040380 \\
{[2.99]^{\star \star \star}}\end{array}$ & $\begin{array}{l}0.168499 \\
{[9.95]^{\star \star \star}}\end{array}$ \\
\hline $\begin{array}{l}\text { Single with } \\
\text { child }\end{array}$ & $\begin{array}{l}0.142885 \\
{[7.65]^{\star \star \star}}\end{array}$ & $\begin{array}{l}0.077391 \\
{[5.67]^{\star \star \star}}\end{array}$ & $\begin{array}{l}0.127228 \\
{[10.42]^{\star \star \star}}\end{array}$ & $\begin{array}{l}-0.045282 \\
{[2.37]^{\star \star}}\end{array}$ & $\begin{array}{l}0.198915 \\
{[13.07]^{\star \star \star}}\end{array}$ & $\begin{array}{l}0.103333 \\
{[7.35]^{\star \star \star}}\end{array}$ & $\begin{array}{l}-0.075306 \\
{[5.94]^{\star \star \star}}\end{array}$ & $\begin{array}{l}0.319758 \\
{[13.23]^{\star \star \star}}\end{array}$ \\
\hline 1 child & $\begin{array}{l}-0.035908 \\
{[2.59]^{\star \star \star}}\end{array}$ & $\begin{array}{l}-0.054033 \\
{[4.22]^{\star \star \star}}\end{array}$ & $\begin{array}{l}-0.042814 \\
{[3.44]^{\star \star \star}}\end{array}$ & $\begin{array}{l}-0.072858 \\
{[4.90]^{\star \star \star}}\end{array}$ & $\begin{array}{l}-0.022240 \\
{[3.00]^{\star \star \star}}\end{array}$ & $\begin{array}{l}-0.128189 \\
{[11.55]^{\star \star \star}}\end{array}$ & $\begin{array}{l}-0.076637 \\
{[7.62]^{\star \star \star}}\end{array}$ & $\begin{array}{l}-0.055298 \\
{[5.13]^{\star \star \star}}\end{array}$ \\
\hline 2 children & $\begin{array}{l}-0.064088 \\
{[4.34]^{\star \star \star}}\end{array}$ & $\begin{array}{l}-0.076245 \\
{[4.83]^{\star \star \star}}\end{array}$ & $\begin{array}{l}-0.071343 \\
{[6.52]^{\star \star \star}}\end{array}$ & $\begin{array}{l}-0.095463 \\
{[6.33]^{\star \star \star}}\end{array}$ & $\begin{array}{l}-0.020754 \\
{[2.78]^{\star \star \star}}\end{array}$ & $\begin{array}{l}-0.098431 \\
{[8.48]^{\star \star \star}}\end{array}$ & $\begin{array}{l}-0.080417 \\
{[7.36]^{\star \star \star}}\end{array}$ & $\begin{array}{l}-0.023299 \\
{[1.90]^{\star}}\end{array}$ \\
\hline 3 children & & $\begin{array}{l}-0.092794 \\
{[1.10]}\end{array}$ & $\begin{array}{l}0.083959 \\
{[0.50]}\end{array}$ & $\begin{array}{l}0.031229 \\
{[0.25]}\end{array}$ & $\begin{array}{l}-0.103193 \\
{[1.94]^{\star}}\end{array}$ & $\begin{array}{l}0.157705 \\
{[1.56]}\end{array}$ & $\begin{array}{l}-0.053633 \\
{[0.34]}\end{array}$ & $\begin{array}{l}0.031769 \\
{[0.26]}\end{array}$ \\
\hline 5 children & & $\begin{array}{l}-0.065198 \\
{[0.91]}\end{array}$ & $\begin{array}{l}0.425717 \\
{[3.62]^{\star \star \star}}\end{array}$ & & $\begin{array}{l}0.071388 \\
{[0.48]}\end{array}$ & $\begin{array}{l}-0.211233 \\
{[2.09]^{\star \star}}\end{array}$ & $\begin{array}{l}0.031233 \\
{[0.25]}\end{array}$ & \\
\hline 2 hh members & $\begin{array}{l}-0.076292 \\
{[4.27]^{\star \star \star}}\end{array}$ & $\begin{array}{l}-0.167278 \\
{[11.18]^{\star \star \star}}\end{array}$ & $\begin{array}{l}-0.116283 \\
{[7.79]^{\star \star \star}}\end{array}$ & $\begin{array}{l}-0.203405 \\
{[9.16]^{\star \star \star}}\end{array}$ & $\begin{array}{l}-0.106396 \\
{[12.61]^{\star \star \star}}\end{array}$ & $\begin{array}{l}-0.009741 \\
{[0.58]}\end{array}$ & $\begin{array}{l}-0.154515 \\
{[11.09]^{\star \star \star}}\end{array}$ & $\begin{array}{l}-0.019411 \\
{[1.25]}\end{array}$ \\
\hline $3 \mathrm{hh}$ members & $\mid \begin{array}{l}-0.111212 \\
{[5.59]^{\star \star \star}}\end{array}$ & $\begin{array}{l}-0.206845 \\
{[13.20]^{\star \star \star}}\end{array}$ & $\begin{array}{l}-0.164739 \\
{[9.25]^{\star \star \star}}\end{array}$ & $\begin{array}{l}-0.316457 \\
{[11.93]^{\star \star \star}}\end{array}$ & $\begin{array}{l}-0.138972 \\
{[16.64]^{\star \star \star}}\end{array}$ & $\begin{array}{l}-0.032461 \\
{[1.60]}\end{array}$ & $\begin{array}{l}-0.224880 \\
{[15.10]^{\star \star \star}}\end{array}$ & $\begin{array}{l}-0.030013 \\
{[1.77]^{\star}}\end{array}$ \\
\hline $4 \mathrm{hh}$ members & $\begin{array}{l}-0.150495 \\
{[5.81]^{\star \star \star}}\end{array}$ & $\begin{array}{l}-0.279045 \\
{[12.64]^{\star \star \star}}\end{array}$ & $\begin{array}{l}-0.236811 \\
{[9.89]^{\star \star \star}}\end{array}$ & $\begin{array}{l}-0.382663 \\
{[10.96]^{\star \star \star}}\end{array}$ & $\begin{array}{l}-0.174711 \\
{[17.61]^{\star \star \star}}\end{array}$ & $\begin{array}{l}-0.046273 \\
{[1.77]^{\star}}\end{array}$ & $\begin{array}{l}-0.281952 \\
{[14.18]^{\star \star \star}}\end{array}$ & $\begin{array}{l}-0.036408 \\
{[1.82]^{\star}}\end{array}$ \\
\hline $5 \mathrm{hh}$ members & {$\left[\begin{array}{l}-0.145197 \\
{[5.73]^{\star \star \star}}\end{array}\right.$} & $\begin{array}{l}-0.242057 \\
{[11.13]^{\star \star \star}}\end{array}$ & $\begin{array}{l}-0.201120 \\
{[6.02]^{\star \star \star}}\end{array}$ & $\begin{array}{l}-0.322461 \\
{[6.97]^{\star \star \star}}\end{array}$ & $\begin{array}{l}-0.132113 \\
{[12.52]^{\star \star \star}}\end{array}$ & $\begin{array}{l}-0.063315 \\
{[1.21]}\end{array}$ & $\begin{array}{l}-0.246618 \\
{[11.31]^{\star \star \star}}\end{array}$ & $\begin{array}{l}-0.017337 \\
{[0.82]}\end{array}$ \\
\hline 6 hh members & $\begin{array}{l}-0.142426 \\
{[5.03]^{\star \star \star}}\end{array}$ & $\begin{array}{l}-0.279350 \\
{[14.49]^{\star \star \star}}\end{array}$ & $\begin{array}{l}-0.272898 \\
{[11.53]^{\star \star \star}}\end{array}$ & $\begin{array}{l}-0.431563 \\
{[12.38]^{\star \star \star}}\end{array}$ & $\begin{array}{l}-0.178332 \\
{[18.75]^{\star \star \star}}\end{array}$ & $\begin{array}{l}-0.092607 \\
{[3.13]^{\star \star \star}}\end{array}$ & $\begin{array}{l}-0.304162 \\
{[15.95]^{\star \star \star}}\end{array}$ & $\begin{array}{l}-0.050867 \\
{[2.31]^{\star \star}}\end{array}$ \\
\hline 7 hh members & $\begin{array}{l}-0.176869 \\
{[5.93]^{\star \star \star}}\end{array}$ & $\begin{array}{l}-0.292810 \\
{[15.02]^{\star \star \star}}\end{array}$ & $\begin{array}{l}-0.299255 \\
{[12.75]^{\star \star \star}}\end{array}$ & $\begin{array}{l}-0.437108 \\
{[12.66]^{\star \star \star}}\end{array}$ & $\begin{array}{l}-0.192942 \\
{[20.00]^{\star \star \star}}\end{array}$ & $\begin{array}{l}-0.147417 \\
{[4.35]^{\star \star \star}}\end{array}$ & $\begin{array}{l}-0.312948 \\
{[16.15]^{\star \star \star}}\end{array}$ & $\begin{array}{l}-0.060147 \\
{[2.70]^{\star \star \star}}\end{array}$ \\
\hline $\begin{array}{c}\text { Densly } \\
\text { populated }\end{array}$ & $\begin{array}{l}-0.017173 \\
{[2.13]^{\star \star}}\end{array}$ & $\begin{array}{l}0.007439 \\
{[1.26]}\end{array}$ & $\begin{array}{l}-0.040160 \\
{[7.33]^{\star \star \star}}\end{array}$ & $\begin{array}{l}-0.058606 \\
{[7.59]^{\star \star \star}}\end{array}$ & $\begin{array}{l}-0.022795 \\
{[5.26]^{\star \star \star}}\end{array}$ & $\begin{array}{l}-0.035005 \\
{[4.14]^{\star \star \star}}\end{array}$ & $\begin{array}{l}-0.012517 \\
{[2.18]^{\star \star}}\end{array}$ & $\begin{array}{l}-0.014900 \\
{[1.20]}\end{array}$ \\
\hline $\begin{array}{c}\text { Thinly } \\
\text { populated }\end{array}$ & $\begin{array}{l}0.009419 \\
{[1.30]}\end{array}$ & $\begin{array}{l}-0.030347 \\
{[2.27]^{\star \star}}\end{array}$ & $\begin{array}{l}0.043371 \\
{[6.08]^{\star \star \star}}\end{array}$ & $\begin{array}{l}0.038131 \\
{[5.20]^{\star \star \star}}\end{array}$ & $\begin{array}{l}0.015920 \\
{[3.50]^{\star \star \star}}\end{array}$ & $\begin{array}{l}0.018551 \\
{[2.70]^{\star \star \star}}\end{array}$ & $\begin{array}{l}-0.009317 \\
{[1.34]}\end{array}$ & $\begin{array}{l}0.007952 \\
{[0.63]}\end{array}$ \\
\hline $\begin{array}{l}\text { Year } \\
\text { dummies }\end{array}$ & Yes & Yes & Yes & Yes & Yes & Yes & Yes & Yes \\
\hline $\begin{array}{l}\text { Regional } \\
\text { dummies }\end{array}$ & Yes & Yes & Yes & Yes & Yes & Yes & Yes & Yes \\
\hline Observations & 55218 & 52685 & 102228 & 60350 & 147794 & 112510 & 96344 & 63697 \\
\hline $\begin{array}{l}\text { Pseudo R- } \\
\text { squared }\end{array}$ & 0.47 & 0.45 & 0.44 & 0.37 & 0.39 & 0.39 & 0.45 & 0.51 \\
\hline
\end{tabular}

Notes: z statistics in brackets; * significant at 10per cent; ** significant at 5per cent; *** significant at 1per cent; the EU-SILC does not distinguish between EU-25 and extra EU-25 migrants; ${ }^{++}$migrants identified by country of birth; the EU-SILC does not distinguish between EU-25 and extra EU-25 migrants. Low income variable defined as equivalized income lower than 60 per cent of median income; High income variable defined as equivailzed income greater tnan $4 / 3$ of median income. 
Table A2. The probability of receiving contributory-benefits: individual probit regressions

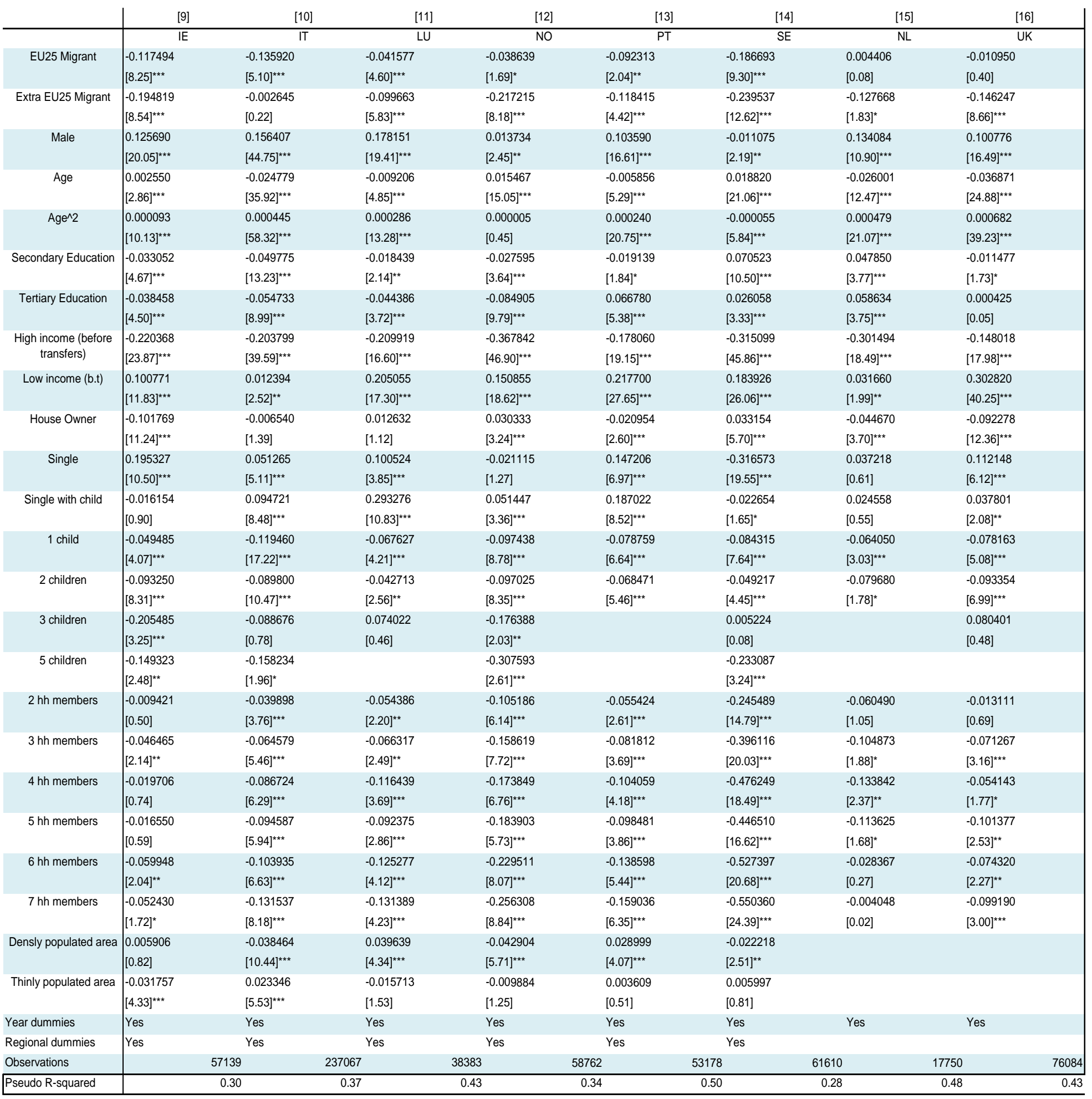

Notes: z statistics in brackets; * significant at 10per cent; ** significant at 5per cent; *** significant at 1per cent; ${ }^{+}$ the EU-SILC does not distinguish between EU-25 and extra EU-25 migrants; ${ }^{++}$migrants identified by country of birth; the EU-SILC does not distinguish between EU-25 and extra EU-25 migrants. Low income variable defined as 
equivalized income lower than 60 per cent of median income; High income variable defined as equivailzed income greater tnan $4 / 3$ of median income. 
Table A3. The probability of receiving non-contributory allowances: household probit regressions

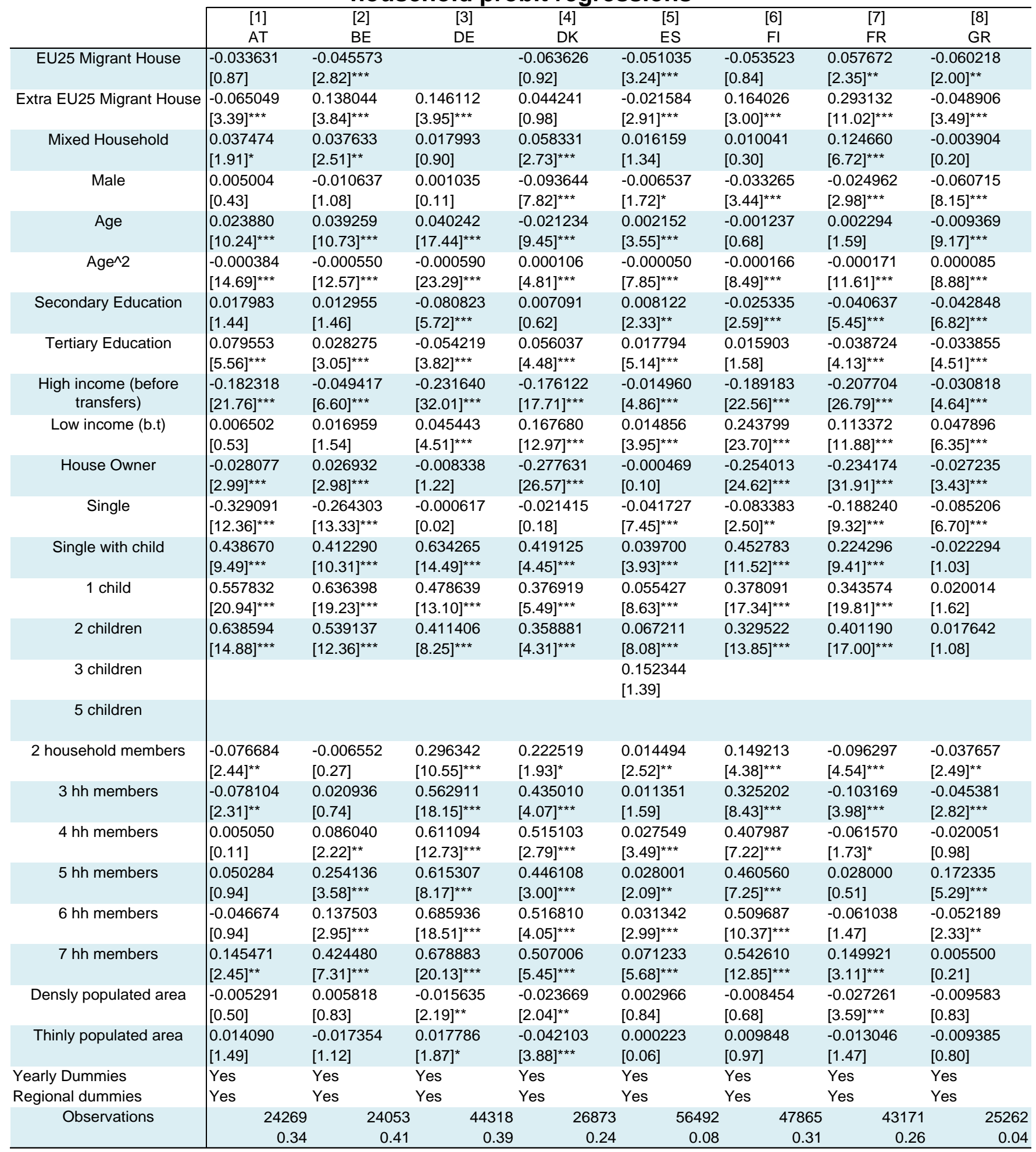

Notes: z statistics in brackets; * significant at 10per cent; ** significant at 5per cent; *** significant at 1per cent; ${ }^{+}$ the EU-SILC does not distinguish between EU-25 and extra EU-25 migrants; ${ }^{++}$migrants identified by country of birth; the EU-SILC does not distinguish between EU-25 and extra EU-25 migrants. Low income variable defined as equivalized income lower than 60 per cent of median income; High income variable defined as equivailzed income greater tnan $4 / 3$ of median income. 
Table A3. The probability of receiving non-contributory allowances: household probit regressions

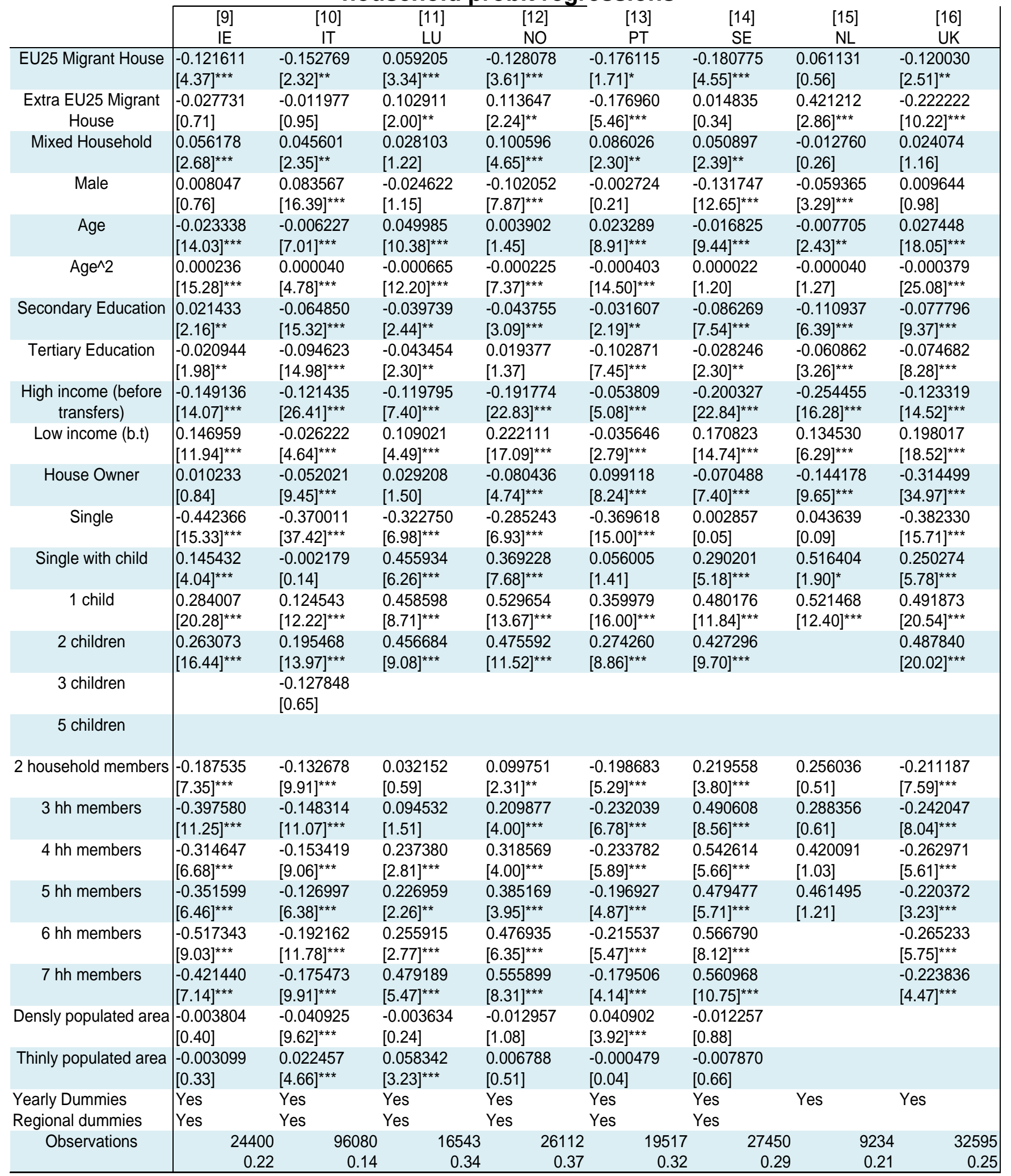

Notes: z statistics in brackets; * significant at 10per cent; ** significant at 5per cent; *** significant at 1 per cent; ${ }^{+}$ the EU-SILC does not distinguish between EU-25 and extra EU-25 migrants; ${ }^{++}$migrants identified by country of 
birth; the EU-SILC does not distinguish between EU-25 and extra EU-25 migrants. Low income variable defined as equivalized income lower than 60 per cent of median income; High income variable defined as equivailzed income greater tnan $4 / 3$ of median income. 


\section{ANNEX B: THE MIGRATION POLICY INDEX}

The fRDB index on migration collects information on twelve EU15 countries, from 1994 to 2005, along seven different dimensions:

1. The number of certificates and procedures needed to be admitted as a foreigner, whatever the motivations may be.

2. The number of certification or procedures required to legally reside in the territory. This differs from the requirements for entering the country as holding a valid document is typically not sufficient.

3. The number of years required to obtain a permanent residence permit.

4. The number of administrations involved

5. The number of years of stay required to obtain a first residence permit.

6. The existence of a quota system

7. Regulations as to asylum policy (developed from Hatton, 2004).

The 7 dimensions were initially expressed either in different units or in an ordinal scale. To make those measures comparable, we converted them in cardinal scores and we normalized them to a range from 0 to 6 , with higher score representing stricter regulation.

As a last step, we computed an overall summary indicator for each country, averaging the values of the seven sub-indexes.

The indicator of reform activity for highly skilled workers assumes three values: "- 1 " if the reform is permissive, “ 0 ” if neutral, and “ 1 ” if stringent.

We define a reform as permissive if:

- it lowers requirements for entry and to obtain residence or work permits

- it introduces temporary permits

- it reduces the number of years to obtain permanent residence permit

- it helps the integration of migrants into the community

On the other hand, a reform is considered as restrictive if:

- it introduces a quota system to entry

- it increases requirements for entry and to obtain residence or work permits

- it raises the number of years to obtain permanent residence permit and it introduces residence constraints

A reform is neutral if it doesn't affect the current legislation concerning immigration. 